\title{
Light energy partitioning, photosynthetic efficiency and biomass allocation in invasive Prunus serotina and native Quercus petraea in relation to light environment, competition and allelopathy
}

\author{
Piotr Robakowski $^{1}$ (D) Ernest Bielinis ${ }^{1,2} \cdot$ Kerrie Sendall $^{3}$
}

Received: 3 September 2017 / Accepted: 4 January 2018 / Published online: 7 February 2018

(c) The Author(s) 2018. This article is an open access publication

\begin{abstract}
This study addressed whether competition under different light environments was reflected by changes in leaf absorbed light energy partitioning, photosynthetic efficiency, relative growth rate and biomass allocation in invasive and native competitors. Additionally, a potential allelopathic effect of mulching with invasive Prunus serotina leaves on native Quercus petraea growth and photosynthesis was tested. The effect of light environment on leaf absorbed light energy partitioning and photosynthetic characteristics was more pronounced than the effects of interspecific competition and allelopathy. The quantum yield of PSII of invasive $P$. serotina increased in the presence of a competitor, indicating a higher plasticity in energy partitioning for the invasive over the native $Q$. petraea, giving it a competitive advantage. The most striking difference between the two study species was the higher crown-level net $\mathrm{CO}_{2}$ assimilation rates $\left(\mathrm{A}_{\text {crown }}\right)$ of $P$. serotina compared with $Q$. petraea. At the juvenile life stage, higher relative growth rate and higher biomass allocation to foliage allowed $P$. serotina to absorb and use light energy for photosynthesis more efficiently than $Q$. petraea. Species-specific strategies of growth, biomass allocation, light energy partitioning and photosynthetic efficiency varied with the light environment and gave an advantage to the invader over its native competitor in competition for light. However, higher biomass allocation to roots in $Q$. petraea allows for greater belowground competition for water and nutrients as compared to $P$. serotina. This niche differentiation may compensate for the lower aboveground competitiveness of the native species and explain its ability to co-occur with the invasive competitor in natural forest settings.
\end{abstract}

Keywords Acclimation to light $\cdot$ Chlorophyll $a$ fluorescence $\cdot$ Competition $\cdot$ Energy partitioning $\cdot \mathrm{Net}^{\mathrm{CO}_{2}}$ assimilation rate $\cdot$ Photosynthetic efficiency

Electronic supplementary material The online version of this article (https://doi.org/10.1007/s10265-018-1009-x) contains supplementary material, which is available to authorized users.

Piotr Robakowski pierrot@up.poznan.pl

1 Department of Forestry, Poznan University of Life Sciences, Wojska Polskiego 71E St., 60-625 Poznan, Poland

2 Unit of Forestry and Forest Ecology, Department of Environmental Management and Agriculture, University of Warmia and Mazury in Olsztyn, PL Lodzki 2, 10-727 Olsztyn, Poland

3 Department of Biology, Georgia Southern University, P.O. Box 8042, Statesboro, GA 30460, USA

\section{Introduction}

Competition among trees results from genetically founded species-specific and ontogenetic differences in growth dynamics, maximum net $\mathrm{CO}_{2}$ assimilation rate $\left(\mathrm{A}_{\max }\right)$, leaf nitrogen concentration $\left(\mathrm{N}_{\text {mass }}\right)$ and requirements for nutrients, water and light (Craine and Dybzinski 2013; Reich et al. 1992). On a global scale across biomes and plant functional groups there is evidence that key leaf traits such as specific leaf area (SLA), $\mathrm{N}_{\text {mass }}, \mathrm{A}_{\max }$ and dark respiration $\left(R_{d}\right)$ are positively related (Reich et al. 1998). The species and individuals which grow faster and overtop competitors are better adapted to win the battle for light, thus increasing their photosynthetic and growth performance (Balandier 2005; Novoplansky 2009; Peet and Christensen 1987). In natural conditions, however, it is difficult to distinguish the effects of different environmental factors on plant 
performance from plant-plant competitive interactions or allelochemical relations. The outcomes of plant competition can be identified more easily in controlled conditions. Here, in a pot experiment, we simulated the relationship between Quercus petraea and Prunus serotina seedlings under the canopy of a Scots pine forest, which has been observed in natural conditions.

Growth and photosynthetic competition occur when a plant is able to increase or maintain rates of growth and/ or photosynthesis, while reducing rates of its competitor (Grime 1974, 1977). A major aspect of photosynthetic competition involves competing for light, water and nutrients required for photosynthesis. An outcome of competition may be the ability of a plant to acclimatize or adapt its photosynthetic apparatus and functions to meet the altered availability of photosynthetic substrates. A species may gain an advantage over its competitor via its capacity to acclimate from low to high light regimes, its higher photosynthetic capacity in high light, or higher leaf anatomical plasticity in response to changing light (Baker 1965; Daehler 2003; Oguchi et al. 2008; Valladares et al. 2000). For example, in cool-temperate deciduous forests, a trade-off between photosynthetic plasticity and shade tolerance was observed in response to gap formation and increased light availability (Oguchi et al. 2017). Gap-dependent species were more plastic and developed leaves with new traits that allowed for fast growth, whereas gap-independent species sacrified photosynthetic plasticity in order to maintain shade tolerance (Oguchi et al. 2017). Additionally, invasive species exhibit higher plasticity in terms of biomass allocation and many leaf traits in response to nutrient availability (Funk 2008). A prior comparison of invasive $P$. serotina and native $Q$. petraea growth dynamics showed that the former is a superior competitor for light under introduced conditions (Robakowski and Bielinis 2011). Here, we address whether the competitive advantage observed in invasive $P$. serotina occurs as a result of higher photosynthetic capacity.

The leading hypothesis explaining the mechanism of plant invasion (the enemy release hypothesis) states that invasive species escape from natural enemies and develop novel competitive abilities in a new environment (Bais et al. 2003; Keane and Crawley 2002). For example, Reinhart et al. (2003) provided evidence that the invasiveness of $P$. serotina in Europe was due in part to its escape from Pythium spp., a primary competitor in its native range. Our observations and preliminary results (Robakowski and Bielinis 2011), however, suggest that the resource-enemy release hypothesis, in which the enemy release hypothesis and increased resource availability act in concert, may more accurately explain the invasion of $P$. serotina in Europe (Blumenthal 2005).

It is important to note that a great number of species perform similarly in introduced ranges when compared with their conspecific populations in their native range (Alba and Hufbauer 2012; Parker et al. 2013). Species that perform similarly in introduced and native habitats are generally referred to as non-native, while those that are more competitive in introduced habitats are referred to as invasive (Parker et al. 2013; van Kleunen et al. 2010). Under new environmental conditions, an invasive species may be larger in size, exhibit higher reproductive performance and resource use efficiency, and have lower biomass production costs than in its native habitat. Invasive plants often inhibit the growth of competitors and are highly efficient at capturing and utilising light, water, mineral nutrients and space (Heberling and Fridley 2013; van Kleunen et al. 2010).

Allelochemical activity has been proposed as an alternative explanation for the success of some invasive species (Callaway and Aschehoug 2000; Hierro and Callaway 2003). In an introduced environment, an invasive species may use a "new weapon" to compete more efficiently with native species (Yuan et al. 2013). For example, some invasive species use allelochemicals volatilized from leaves or released from roots as exudate in soil (Koutika et al. 2007; Ubalua 2010). Bais et al. (2003) showed that invasive Centaurea maculosa inhibited growth and germination of native species in field soils with the phytotoxin (-)-catechin released from its roots. In the present study, we investigate the effect of a cyanogenic glycoside, prunasin, which is produced by the invasive $P$. serotina and is known for its allelochemical properties (Leavesley et al. 2008; Robakowski et al. 2016; Swain et al. 1992; Vetter 2000). Our earlier paper (Robakowski et al. 2016) was focused on seasonal changes in root prunasin concentrations of $P$. serotina and correlations among prunasin concentration and different ecophysiological parameters.

To understand the mechanism of invasion, invasive species have been compared with their native congeners with respect to growth and photosynthetic traits (McDowell 2002; van Kleunen et al. 2010). The advantage of comparing congeners rather than unrelated species is that the comparison of congeners provides more insight into which traits actually play a role in the invasiveness of a species and which are merely coincidental (Mack 1996; McDowell 2002). Photosynthetic and growth characteristics of invasive plants have also been compared between invasive species and non-invasive, unrelated native species (Baruch and Goldstein 1999; Pattison et al. 1998). Functionally similar species are more likely to compete (Abrams 1983), but if an invasive species and a native species are functionally similar, the invasive species may lack the competitive advantage needed to outgrow the native species (Davis et al. 2000). P. serotina and $Q$. petraea used in our study are broadleaved deciduous trees originating from different families, but they share the same ecological niche in European forests. 
Invasive species often have different suites of leaf traits when compared with native species. For instance, invasive species have been shown to have higher photosynthetic capacity, higher photosynthetic nitrogen and water use efficiency (PNUE and WUE, respectively), greater instantaneous photosynthetic energy-use efficiency, lower respiration costs, lower construction costs of leaf tissue, and lower leaf mass to area ratio (LMA) when compared with native species (Heberling and Fridley 2013; McDowell 2002). Invasive species, however, do not have fundamentally different carbon capture strategies from natives, but are instead positioned further along the leaf economics spectrum towards faster growth strategies (Leishman et al. 2007). On a global scale, plants with lower LMA are more efficient at light interception per unit leaf dry mass than those with higher LMA (Wright et al. 2004). Species that best compete for light under shaded conditions are highly efficient at light capture due to higher allocation of resources to light harvesting complexes, increased chlorophyll concentrations and reductions of chlorophyll a/b ratios (Hikosaka and Terashima 1996; Lei and Lechowicz 1998). In high light, high leaf nitrogen concentration and photosynthetic capacity, as well as effective mechanisms of dissipating excess energy, can confer an advantage in competition for resources (Demmig-Adams and Adams 1996, 2006; Heberling and Fridley 2013).

The photosynthetic performance of our study trees was determined by comparing the fraction of leaf absorbed light energy transferred to photochemistry $\left(\Phi_{\mathrm{PSII}}\right)$ vs. heat $\left(\Phi_{\mathrm{NPQ}}\right)$ and fluorescence $\left(\Phi_{\mathrm{f}, \mathrm{D}}\right)$. This partitioning of leaf absorbed light energy depends on factors such as temperature and light availability. Species and individuals allocating high levels of energy to photochemistry have potentially higher net $\mathrm{CO}_{2}$ assimilation rates compared to plants that dissipate more energy as heat and fluorescence (Genty et al. 1989; Maxwell and Johnson 2000). In the present study, we have posited that $P$. serotina and $Q$. petraea will differ in terms of proportions of leaf absorbed light energy transferred to different processes, with a higher proportion of energy allocated to $\Phi_{\text {PSII }}$ in the species with a competitive advantage (Funk 2008). However, under non-optimal conditions, as was the case in the strong shade and high light treatments in our experiment, photochemical energy can be used in several alternative pathways such as photorespiration, the Mehler reaction or the xanthophyll cycle, which may lead to a reduction in the rate of net $\mathrm{CO}_{2}$ assimilation (Demmig-Adams et al. 1996; Demmig-Adams and Adams 2006; DemmigAdams and Niyogi 1999). In addition to variation in leaf absorbed light energy partitioning, we expected our different competition and allelochemical treatment combinations (see details below) to influence leaf structure (LMA), physiology (respiration, net $\mathrm{CO}_{2}$ assimilation rates), and biomass allocation to different organs as was shown for Picea abies and Fagus sylvatica in Kozovits et al. (2005).
The aim of our study was to determine the mechanisms of competitive interactions between invasive $P$. serotina and native $Q$. petraea. To achieve this, we measured leaf absorbed light energy partitioning and photosynthetic and growth rates of seedlings in response to variations in light environment, competition, and allelopathic effects by mulching with $P$. serotina leaves. The following hypotheses were tested: (1) invasive $P$. serotina will invest more energy in $\Phi_{\mathrm{PSII}}$ rather than in $\Phi_{\mathrm{NPQ}}$ and $\Phi_{\mathrm{f}, \mathrm{D}}$ when growing in competition with native $Q$. petraea than it will when growing in monoculture. In contrast, native $Q$. petraea will not increase energy transfer to $\Phi_{\mathrm{PSII}}$ when growing in the presence of $P$. serotina and/or allelopathic compounds. Lower losses of leaf absorbed light energy and higher $\Phi_{\mathrm{PSII}}$ will give an advantage to the invasive over the native species in photosynthetic performance and growth. This hypothesis is supported by the results of Funk (2008) who showed that effective quantum yield of fluorescence can be higher in invasive compared with native species. Alternatively, Hendrickson et al. (2004) found that partitioning of leaf absorbed light energy was driven more by light availability than by interspecific competition. (2) When competing with $Q$. petraea, $P$. serotina will enhance its photosynthetic capacity and resource use efficiency to increase growth at lower costs and compete for aboveground resources more effectively than the native species. In contrast, in the presence of the invasive competitor and/or allelopathic effects of $P$. serotina leaves, $Q$. petraea will decrease its photosynthetic capacity and resource use efficiency. Earlier results from other studies suggest that there is not a clear difference between native and invasive species in terms of absolute rates of photosynthetic capacity and resource use efficiency, but invasives do appear to have higher plasticity of the latter (Daehler 2003; Funk 2008). (3) Effects of competition and/or allelopathy on photosynthesis will be more pronounced under high light than under intermediate and low light levels. In high light, the competing species will assimilate more carbon and thus be able to allocate more biomass to photosynthesis and growth, which will result in intense competition for space and light. In contrast, under strong shade, seedlings will reduce growth and photosynthesis independent of species or treatment and competition will be minimal or absent. Oguchi et al. (2017) found that species-specific photosynthetic responses to increased light availability in forest trees can influence their interspecific competition. Based on 79 independent native-invasive plant comparisons, Daehler (2003) stated that increased resource availability increased the performance of invasive species over that of natives. (4) P. serotina leaves used as a source of allelochemicals in mulching will inhibit growth, respiration and photosynthesis of native $Q$. petraea. Leaves contain the allelochemical prunasin that, after being hydrolyzed, decomposes into hydrogen cyanide $(\mathrm{HCN})$, a respiratory poison that inhibits the activity of metalloenzymes 
such as cytochrome $c$ oxidase (Leavesley et al. 2008; Swain et al. 1992; Vetter 2000). (5) At the juvenile stage, invasive $P$. serotina will experience higher growth rates and higher biomass allocation to leaves than roots, while native $Q$. petraea will allocate more growth toward roots at the expense of leaves. This hypothesis is based on our observations of natural regeneration of both species in forest understories and preliminary research showing that the growth rates of $P$. serotina can be several times greater than that of $Q$. petraea (Robakowski and Bielinis 2011). It is also supported by earlier studies from Kozovits et al. (2005) who showed that Picea abies was a stronger competitor than Fagus sylvatica due to higher above-ground biomass increments in mixed culture than in monoculture.

\section{Materials and methods}

\section{Material}

Prunus serotina (Ehrh.) Borkh. is a deciduous tree or a small understorey shrub that is native to North America (Forestry Compendium 2005; Marquis 1990). As juveniles, the species is classified as moderately shade tolerant, showing the highest growth rate in $25 \%$ of full sun and only slightly lower in $100 \%$ (Robakowski, unpublished). The species exhibits the "sit and wait" life strategy, i.e. seedlings are able to survive beneath the dense canopy, but grow quickly in the high light of forest clearings and gaps (Closset-Kopp et al. 2011). The species is able to rapidly occupy new territories due to mass and frequent seed production, propagation of seeds by birds, resprouting from trunks and roots, and high rates of annual growth. It is an aggressive colonizer, capable of rapidly overtopping native tree species when introduced to new habitats (Csiszár et al. 2013; Halarewicz 2011; Möllerová 2005).

Quercus petraea (Matt.) Liebl. is an economically important deciduous broadleaved tree occurring in Europe. As juveniles, $Q$. petraea is classified as shade-tolerant. In Poland and Germany, natural regeneration of $Q$. petraea is favoured beneath the canopy of Pinus sylvestris (L.) stands of different age (Kenk 1993), occurring together with the natural regeneration of $P$. serotina. When naturally regenerating in forest understories such as our experimental forest, $P$. serotina tends to be at least twice as common (up to 120 seedlings per $\mathrm{m}^{2}$ ) as $Q$. petraea, and in this study we were attempting to simulate this competition. Thus, we planted a higher number of seedlings of the invasive species in each competition treatment since it accurately reflected the observed pressure of $P$. serotina on $Q$. petraea. The greater regeneration density of $P$. serotina compared with $Q$. petraea is likely due to more frequent and abundant seed production, accumulation of seeds in soil and high seed germination capacity even after 5 years of being in soil, distribution of seeds by birds, higher capacity of vegetative regeneration and much higher growth rates at the juvenile life stage. Additionally, our observations indicate that in the university experimental forest $P$. serotina is not browsed by deer and roes, while $Q$. petraea seedlings and saplings are often damaged by these animals. In addition, $Q$. petraea acorns are eaten by deer, wild boar, squirrels and other animal species. $P$. serotina seeds, leaves and roots contain the cyanogenic glycosides amygdalin and/or prunasin, which repel animals.

In October 2011, acorns of Q. petraea were collected in a selected seed stand located in Jarocin Forest Division, Western Poland. At the end of February 2012, acorns were potted in a peat and perlite substrate $(3: 1 ; \mathrm{v} / \mathrm{v})$ and grown in a plastic tunnel without heating at the Jarocin forest nursery $\left(51^{\circ} 58^{\prime} 45^{\prime \prime} \mathrm{N} ; 17^{\circ} 29^{\prime} 8^{\prime \prime} \mathrm{E}\right)$. Seedlings were moved outdoors at the end of March. P. serotina seedlings originated from the natural regeneration occurring in "Zielonka" Forest, $27 \mathrm{~km}$ from Poznan, Western Poland (52 $\left.33^{\prime} 29^{\prime \prime} \mathrm{N} ; 1^{\circ} 06^{\prime} 18^{\prime \prime} \mathrm{E}\right)$. At the beginning of May 2012, 1-year-old seedlings were dug up and transported with roots thoroughly covered with humus to Poznan University of Life Sciences Dendrological Garden.

Quercus and Prunus seedlings were potted using 225 7-1 pots filled with a mixture of $\mathrm{pH}$-neutral sand, peat and humus $(1 / 1 / 1 ; \mathrm{v} / \mathrm{v} / \mathrm{v})$. For better drainage, a small amount of gravel was added at the bottom of pots. Before planting, $100 \mathrm{~g}$ of fresh $P$. serotina leaves, cut into small pieces $\left(\sim 0.25 \mathrm{~cm}^{2}\right)$, were added to each of 90 pots and mixed with the substrate to enhance the expected allelopathic reaction. Mulching was repeated once a month from May to September with $10 \mathrm{~g}$ of freshly cut $P$. serotina leaves. Leaves of $P$. serotina decomposed almost entirely in pot within around 30 days. In leaves used for mulching, prunasin concentrations were $2.86 \pm 048$ and $15.9 \pm 4.89 \mathrm{mg} \mathrm{g}^{-1} \mathrm{FW}($ mean $\pm \mathrm{SE}$, FW-fresh weight, $n=4$ ) in May and August, respectively. The lowest leaf prunasin concentration was 1.93, and the highest value was $29.93 \mathrm{mg} \mathrm{g}^{-1} \mathrm{FW}$. We used five treatment combinations using different numbers of seedlings and different mulching scenarios: (1) Q: three seedlings of Quercus petraea; (2) P: three seedlings of P. serotina; (3) Q+L: three seedlings of $Q$. petraea + mulching with $P$. serotina leaves; (4) Q + P: three seedlings of $Q$. petraea + six seedlings of $P$. serotina; (5) $\mathrm{Q}+\mathrm{P}+\mathrm{L}$ : three seedlings of $Q$. petraea $+\operatorname{six}$ seedlings of $P$. serotina + mulching. As explained above, $P$. serotina seedlings tend to be at least twice as common as $Q$. petraea seedlings when regenerating in natural conditions. Thus, in order to ensure that adequate competitive pressure on the native species was achieved in our treatments, we used six $P$. serotina seedlings and three $Q$. petraea seedlings in both competition treatments. All combinations are schematically shown in Robakowski et al. (2016). From this point forward, we use variations on these treatment 
combinations to denote which species' measurements are being presented; for example, $\mathrm{P}+\mathrm{Q}$ indicates that traits presented were measured on $P$. serotina seedlings that were competing with $Q$. petraea seedlings, while $\mathrm{Q}+\mathrm{P}$ indicates that traits presented were measured on $Q$. petraea seedlings that were competing $P$. serotina seedlings.

In May 2012, the seedlings were fertilized using $15 \mathrm{~g}$ of slow-releasing fertilizer 'Osmocote Exact Standard' (N, $\mathrm{P}, \mathrm{K}, \mathrm{Mg}-15: 9: 12: 2$ and microelements) per pot. Every 2 days, seedlings were watered to field capacity using an automatic irrigation system. Watering was less intensive in the low light regime (10\% of full light) and was stopped when it was raining. Each month, a subset of pots were emptied and seedlings were harvested for biomass allocation analyses and substrate moisture content was observed. In September, water content in soil was measured gravimetrically and there were no significant differences among light treatments $(P=0.07) . \mathrm{Q}+\mathrm{L}$ had the highest $(46 \%)$ and $\mathrm{Q}+\mathrm{P}$ the lowest $(32 \%)$ water content in substrate $(P<0.001)$. Potted seedlings were grown from half May to the end of November.

\section{Experimental design}

225 pots were distributed into three blocks ( 75 pots per block) and three light treatments, established using a shading net: LL ( $10 \%$ of full sun), ML ( $25 \%$ of full sun) and HL ( $100 \%$ of full sun). The spectral proprieties of the material used for the shading net have been described in Robakowski (2005). There were 25 pots in each block by light treatment. Five combinations of seedlings with or without mulching (Table 1) were distributed in split-plots (five pots per block, light treatment and combination). Each combination was repeated five times in each plot i.e. 225 experimental units (5 repetitions $\times 5$ combinations $\times 3$ light treatments $\times 3$ blocks $=225$ pots).

\section{Light treatments and meteorological conditions}

Air temperature and relative humidity $(\mathrm{RH})$ were monitored with HOBO Pro v2 (OnSet Computers, Pocasset, MA, USA) throughout the growing season. Six HOBOs (two per light treatment) were fixed $80 \mathrm{~cm}$ above the ground and registered data every $20 \mathrm{~min}$. Microclimatic differences were most noticeable between shade treatments and HL. Shading decreased monthly mean temperatures, monthly amplitudes and increased relative humidity (RH) compared with HL. The coldest months were May and September $(15.87 \pm 0.15$, $\left.13.86 \pm 0.11{ }^{\circ} \mathrm{C}\right)$, the hottest was August $\left(17.97 \pm 0.12{ }^{\circ} \mathrm{C}\right)$. The differences between HL and ML in monthly mean temperature were $1.62{ }^{\circ} \mathrm{C}$ in June, $1.71{ }^{\circ} \mathrm{C}$ in August, and
Table 1 Effects of light environment and treatment combinations of Prunus serotina and Quercus petraea seedlings with or without mulching on quantum yield of constitutive fluorescence and thermal dissipation $\left(\Phi_{\mathrm{f}, \mathrm{D}}\right)$, quantum yield of thermal energy dissipation $\left(\Phi_{\mathrm{NPQ}}\right)$, and quantum yield of PSII photochemistry $\left(\Phi_{\mathrm{PSII}}\right)$ at $\mathrm{PPF}=295 \mu \mathrm{mol} \mathrm{m} \mathrm{m}^{-2} \mathrm{~s}^{-1}($ mean $\pm \mathrm{SE} ; n=6)$

\begin{tabular}{llll}
\hline Effect & $\Phi_{\mathrm{f}, \mathrm{D}}$ & \multicolumn{1}{c}{$\Phi_{\mathrm{NPQ}}$} & $\Phi_{\mathrm{PSII}}$ \\
\hline \multicolumn{2}{l}{ Prunus serotina } & energy partitioning & \\
$\mathrm{LL}$ & $0.28 \pm 0.01 \mathrm{a}$ & $0.50 \pm 0.02 \mathrm{a}$ & $0.22 \pm 0.01 \mathrm{a}$ \\
$\mathrm{ML}$ & $0.23 \pm 0.01 \mathrm{~b}$ & $0.47 \pm 0.03 \mathrm{ab}$ & $0.30 \pm 0.02 \mathrm{~b}$ \\
$\mathrm{HL}$ & $0.19 \pm 0.01 \mathrm{~b}$ & $0.42 \pm 0.03 \mathrm{~b}$ & $0.39 \pm 0.03 \mathrm{c}$ \\
$\mathrm{P}$ & $0.22 \pm 0.01 \mathrm{a}$ & $0.49 \pm 0.02 \mathrm{a}$ & $0.29 \pm 0.02 \mathrm{a}$ \\
$\mathrm{P}+\mathrm{Q}$ & $0.24 \pm 0.02 \mathrm{a}$ & $0.49 \pm 0.02 \mathrm{a}$ & $0.27 \pm 0.02 \mathrm{a}$ \\
$\mathrm{P}+\mathrm{Q}+\mathrm{L}$ & $0.24 \pm 0.01 \mathrm{a}$ & $0.41 \pm 0.03 \mathrm{~b}$ & $0.35 \pm 0.03 \mathrm{~b}$ \\
Quercus petraea & energy partitioning & \\
LL & $0.26 \pm 0.01 \mathrm{a}$ & $0.47 \pm 0.01 \mathrm{a}$ & $0.27 \pm 0.02 \mathrm{a}$ \\
ML & $0.21 \pm 0.01 \mathrm{a}$ & $0.39 \pm 0.02 \mathrm{ab}$ & $0.40 \pm 0.02 \mathrm{ab}$ \\
$\mathrm{HL}$ & $0.24 \pm 0.01 \mathrm{a}$ & $0.33 \pm 0.02 \mathrm{~b}$ & $0.43 \pm 0.02 \mathrm{~b}$ \\
$\mathrm{Q}$ & $0.24 \pm 0.01 \mathrm{a}$ & $0.37 \pm 0.02 \mathrm{a}$ & $0.39 \pm 0.03 \mathrm{a}$ \\
$\mathrm{Q}+\mathrm{P}$ & $0.25 \pm 0.01 \mathrm{a}$ & $0.38 \pm 0.02 \mathrm{a}$ & $0.37 \pm 0.03 \mathrm{a}$ \\
$\mathrm{Q}+\mathrm{P}+\mathrm{L}$ & $0.23 \pm 0.01 \mathrm{a}$ & $0.42 \pm 0.03 \mathrm{a}$ & $0.35 \pm 0.03 \mathrm{a}$ \\
$\mathrm{Q}+\mathrm{L}$ & $0.23 \pm 0.01 \mathrm{a}$ & $0.41 \pm 0.02 \mathrm{a}$ & $0.36 \pm 0.02 \mathrm{a}$ \\
\hline
\end{tabular}

The same letters after SE in columns indicate that the mean values do not differ significantly among light treatments or among seedlings' combinations in Tukey's test at $P<0.05$

LL, low light ( $10 \%$ of full sun light); ML, medium light ( $25 \%$ of full sun light); HL, high light (100\% of full sun light); P, three Prunus serotina seedlings; $\mathrm{P}+\mathrm{Q}$, six $P$. serotina seedlings in competition with three $Q$. petraea seedlings; $\mathrm{P}+\mathrm{Q}+\mathrm{L}$, six $P$. serotina seedlings in competition with three $Q$. petraea seedlings with mulching with P. serotina leaves; $\mathrm{Q}$, three Quercus petraea seedlings; $\mathrm{Q}+\mathrm{P}$, three Quercus petraea seedlings in competition with six $P$. serotina seedlings; $\mathrm{Q}+\mathrm{P}+\mathrm{L}$, three $Q$. petraea seedlings in competition with six $P$. serotina seedlings with mulching with $P$. serotina leaves; $\mathrm{Q}+\mathrm{L}$, three $Q$. petraea seedlings with mulching with $P$. serotina leaves

$0.97{ }^{\circ} \mathrm{C}$ in September. The lowest $\left(1.34{ }^{\circ} \mathrm{C}\right.$ in September) and the highest temperature $\left(35.90{ }^{\circ} \mathrm{C}\right.$ in August) values were observed in HL.

\section{Light curves of chlorophyll $a$ fluorescence}

Chlorophyll $a$ fluorescence was measured in August 2012 using a Fluorescence Monitoring System (FMS 2, Hansatech, Norfolk, UK) operating in online mode. Six seedlings per species and light treatment (two per block) were randomly chosen and dark-treated for $30 \mathrm{~min}$. in the laboratory prior to measurements of minimal $\left(\mathrm{F}_{0}\right)$ and maximal fluorescence $\left(\mathrm{F}_{\mathrm{m}}\right)$ (Maxwell and Johnson 2000). Each leaf was exposed to modulated measuring light at $0.05 \mu \mathrm{mol}$ $\mathrm{m}^{-2} \mathrm{~s}^{-1}$. After reading $\mathrm{F}_{0}$, a saturating $0.7 \mathrm{~s}$ pulse of light $\left(\mathrm{PPF}=15,300 \mu \mathrm{mol}\right.$ quanta $\mathrm{m}^{-2} \mathrm{~s}^{-1}, \mathrm{PPF}-$ photosynthetic photon flux) was switched on to induce $\mathrm{F}_{\mathrm{m}}$. Maximum quantum yield of PSII photochemistry was calculated using to the 
formula $F_{v} / F_{m}$, where variable fluorescence $F_{v}=F_{m}-F_{0}$. To generate light response curves of PSII quantum yield $\left(\Phi_{\text {PSII }}=\mathrm{F}_{\mathrm{m}}{ }^{\prime}-\mathrm{F}_{\mathrm{s}} / \mathrm{F}_{\mathrm{m}}{ }^{\prime} ; \mathrm{F}_{\mathrm{m}}{ }^{\prime}\right.$-maximal fluorescence in the light, $\mathrm{F}_{\mathrm{s}}$ - steady state fluorescence), the leaf in the clip was illuminated with actinic light of increasing intensity $(0,12$, $38,90,175,295,454,653,894,1177,1503 \mu \mathrm{mol} \mathrm{m}^{-2} \mathrm{~s}^{-1}$ ). For each light level, after a stable steady state fluorescence $\left(\mathrm{F}_{\mathrm{s}}\right)$ was reached, a $0.7 \mathrm{~s}$ saturating pulse was delivered and maximum light-adapted fluorescence $\left(\mathrm{F}_{\mathrm{m}}^{\prime}\right)$ was determined (Rascher et al. 2000). Quantum yield of PSII was calculated according to the methods of Genty et al. (1989).

\section{Mathematical model of leaf absorbed light energy partitioning}

Hendrickson et al. (2004) developed a method to quantify the fate of light energy absorbed by leaves. The following equations were applied to calculate quantum yield of PSII photochemistry $\left(\Phi_{\mathrm{PSII}}\right)$, quantum yield of thermal energy dissipation $\left(\Phi_{\mathrm{NPQ}}\right)$, and quantum yield of constitutive fluorescence and thermal dissipation $\left(\Phi_{\mathrm{f}, \mathrm{D}}\right)$, respectively:

$\boldsymbol{\Phi}_{\text {PSII }}=\mathrm{F}_{\mathrm{m}}^{\prime}-\mathrm{F}_{\mathrm{s}} / \mathrm{F}_{\mathrm{m}}^{\prime}$

$\boldsymbol{\Phi}_{\mathrm{NPQ}}=\mathrm{F}_{\mathrm{s}} / \mathrm{F}_{\mathrm{m}}^{\prime}-\mathrm{F}_{\mathrm{s}} / \mathrm{F}_{\mathrm{m}}$

$\boldsymbol{\Phi}_{\mathrm{f}, \mathrm{D}}=\mathrm{F}_{\mathrm{s}} / \mathrm{F}_{\mathrm{m}}$

To estimate the fractions of energy partitioned to the three processes $\left(\Phi_{\mathrm{PSII}}, \Phi_{\mathrm{NPQ}}, \Phi_{\mathrm{f}, \mathrm{D}}\right)$ the areas below curves representing relationships between PPF of fluorescence induction and respective energy fraction were calculated as sums of products:

$\sum_{\operatorname{PPF}(\mathrm{n})-\mathrm{PPF}(\mathrm{n}-1)}^{1503} \operatorname{PPF} \times(\Phi P S I I$ or $\Phi$ NPQ or $\Phi f, \mathrm{D})$,

where $\mathrm{n}$ - subsequent numbers of the actinic light intensity values used to induce chlorophyll $a$ fluorescence.

\section{Gas exchange}

Methods of gas exchange measurements on P. serotina and $Q$. petraea have been previously described in Robakowski et al. (2016). In brief, gas exchange was measured on four occasions: in June, August, September and October using the gas exchange analyzer LCA-4 (ADC, Ltd., Hoddesdon, UK). The broadleaf chamber (PLC4B) was used, with chamber conditions as follows: $\mathrm{CO}_{2}$ concentration in inlet air of $380 \mu \mathrm{mol} \mathrm{mol}^{-1}$, leaf temperature of 26 to $27{ }^{\circ} \mathrm{C}$, and relative humidity of approximately 55\%. Photosynthetic rates were measured at the saturation $\mathrm{PPF}=1200 \mu \mathrm{mol} \mathrm{m} \mathrm{m}^{-2} \mathrm{~s}^{-1}$. Prior to gas exchange measurements a south-facing leaf was selected from the upper crown. Each leaf was given 20 to
$30 \mathrm{~min}$. to acclimate to the leaf chamber conditions prior to measuring. The window of the leaf chamber was darkened and dark respiration $\left(\mathrm{R}_{\mathrm{d}}, \mu \mathrm{mol} \mathrm{CO} \mathrm{CO}_{2} \mathrm{~m}^{-2} \mathrm{~s}^{-1}\right)$ was measured for $15 \mathrm{~min}$, after which the lamp was switched on and photosynthetic rates were measured for $30 \mathrm{~min}$. Five values from the stable phase of photosynthesis were averaged to obtain maximum net assimilation rate $\left(\mathrm{A}_{\max }, \mathrm{nmol} \mathrm{CO} \mathrm{C}^{-1} \mathrm{~s}^{-1}\right)$. Water use efficiency (WUE, $\mu$ mol $\mathrm{CO}_{2} \mathrm{mmol}^{-1} \mathrm{H}_{2} \mathrm{O}$ ) was calculated as the ratio of area-based maximum photosynthesis $\left(\mu \mathrm{mol} \mathrm{CO} \mathrm{CO}_{2} \mathrm{~m}^{-2} \mathrm{~s}^{-1}\right)$ to transpiration rate $\left(\mathrm{E}, \mathrm{mmol} \mathrm{H}_{2} \mathrm{O}\right.$ $\left.\mathrm{m}^{-2} \mathrm{~s}^{-1}\right)$. Nitrogen concentration was determined from the same leaves as those used for net $\mathrm{CO}_{2}$ assimilation rate to calculate the photosynthetic nitrogen use efficiency (PNUE, $\mu \mathrm{mol} \mathrm{CO}_{2} \mathrm{~mol} \mathrm{~N}^{-1} \mathrm{~s}^{-1}$ ). Projected leaf area and dry mass used for measurements of gas exchange were determined to calculate leaf mass-to-area index (LMA, $\mathrm{g} \mathrm{m}^{-2}$ ) and to calculate the net carbon gain of foliage for each individual $\left(\mathrm{A}_{\text {crown }}, \mathrm{nmol} \mathrm{CO}_{2} \mathrm{~g}^{-1} \mathrm{~s}^{-1}\right)$ by multiplying mass-based photosynthetic rates by the total leaf mass of individual seedlings. Due to the time-consuming nature of gas exchange measurements we were unable to measure these traits on all treatments, and excluded the $\mathrm{P}+\mathrm{Q}($ and $\mathrm{Q}+\mathrm{P}$ ) treatment combinations.

\section{Leaf nitrogen content analyses}

Total nitrogen content was determined using the Kjeldahl method. The digestion of leaf samples was conducted using a digestion system with sulfuric acid at $420^{\circ} \mathrm{C}$ (Foss Tecator). Nitrogen was determined by distillation with water vapour in the apparatus of Parnas-Wagner. Leaf nitrogen content was recalculated per leaf mass and area using LMA.

\section{Leaf area and dry mass of seedlings}

Three seedlings per species, light treatment, competition/ mulching combination and block were used for the biomass allocation analyses. Leaves were scanned and total leaf area was determined with the program DigiShape (Cortex Nova, Poland). Plant organs were then dried at $65^{\circ} \mathrm{C}$ for $48 \mathrm{~h}$ and weighed for dry mass. Relative growth rate (RGR) was calculated according to the formula (Hunt 1982): $\mathrm{RGR}=\frac{\ln \left(\mathrm{W}_{2}\right)-\ln \left(\mathrm{W}_{1}\right)}{\mathrm{t}_{2}-\mathrm{t}_{1}}$, where $\mathrm{W}_{1}$ - mean initial total seedling dry mass calculated using ten seedlings prior to the experiment, $\mathrm{W}_{2}$ - total seedling dry mass at the end of the experiment, $t_{1}$ - day of year 146 (May), $t_{2}$ - day of year 269 (October). Leaf area ratio (LAR) was calculated with the formula: $\mathrm{LAR}=\mathrm{A}_{\mathrm{L}} / \mathrm{W}_{2}$, where $\mathrm{A}_{\mathrm{L}}$ - total seedling leaf area. 


\section{Data analyses}

Prior to the analysis of variance the gas exchange data were logarithmically transformed or function $z=\arcsin \sqrt{p}$ was applied to the data in the form of fractions or percentages to obtain a normal distribution. The effects of block, sampling date, light, combination and their interactions on LMA and photosynthetic parameters of $P$. serotina and $Q$. petraea leaves were analyzed using ANOVA in split-split plot design. ANOVA in split-plot design was also applied to compare the effects of block, light and combination on fractions of energy partitioned to the three processes $\left(\Phi_{\text {PSII }}\right.$, $\left.\Phi_{\mathrm{NPQ}}, \Phi_{\mathrm{f}, \mathrm{D}}\right)$. Analyses were conducted for energy fractions calculated as both the areas beneath the light curves and the values of energy fractions at $\mathrm{PPF}=295 \mu \mathrm{mol} \mathrm{m} \mathrm{m}^{-2} \mathrm{~s}^{-1}$. This value of fluorescence induction PPF was chosen because net $\mathrm{CO}_{2}$ assimilation rates were not light-saturated at this light level and there was no photoinhibition in LL-acclimated seedlings.

For each study species, a two-way ANOVA with interactions was used to compare mean values of RGR among light treatments and competition and mulching combinations. Prior to analyses, RGR values were transformed with $z=\arcsin \sqrt{p}$. A linear regression was used to examine interspecific differences in biomass allocation to leaves vs. roots between the study species. All statistical analyses were conducted using Statistica 12.0 (StatSoft, Inc., USA) and Sigmaplot 13.0 (Systat Software, Inc., USA).

\section{Results}

\section{Partitioning of energy absorbed by leaves}

In LL, both study species exhibited $\Phi_{\mathrm{PSII}}$ of approximately $20 \%$ of total leaf absorbed light energy, which increased to $27-28 \%$ in HL (P. serotina: $F_{2}=47.3, P=0.002$, Fig. 1 , Q. petraea: $F_{2}=6.1, P=0.004$, Fig. 2 ). In Figs. 1 and 2, the percent values indicates the percent area under the curve. $P$. serotina increased $\Phi_{\mathrm{NPQ}}$ from LL to HL, but this was not observed in $Q$. petraea (Figs. 1, 2). Interestingly, under HL, $\Phi_{\mathrm{PSII}}$ was $6 \%$ higher for $P$. serotina in competition with $Q$. petraea and mulching $(\mathrm{P}+\mathrm{Q}+\mathrm{L})$ than in P. serotina monoculture $(\mathrm{P})$ suggesting that the interspecific competition may stimulate an increase in $\Phi_{\mathrm{PSII}}$ of this invasive species (Fig. 1g, i).

In P. serotina, $\Phi_{\mathrm{f}, \mathrm{D}}$ decreased with higher growth light intensity (Fig. 1). In the P treatment, $\Phi_{\mathrm{f}, \mathrm{D}}$ was $7 \%$ higher in LL than in HL (Fig. 1a, g). For $\mathrm{P}+\mathrm{Q}+\mathrm{L}$ and for P. serotina in competition with $Q$. petraea without mulching $(\mathrm{P}+\mathrm{Q})$, $\Phi_{\mathrm{f}, \mathrm{D}}$ was $11 \%$ higher in LL than in HL (Fig. 1b, c, h, i). The LL seedlings of $Q$. petraea showed the highest $\Phi_{\mathrm{f}, \mathrm{D}}$ in all treatments, with ML and HL being lower and not significantly different from each other (Fig. 2).

$\Phi_{\mathrm{f}, \mathrm{D}}, \Phi_{\mathrm{NPQ}}$ and $\Phi_{\mathrm{PSII}}$ were also compared among the light treatments and species combinations at $\mathrm{PPF}=295 \mu \mathrm{mol} \mathrm{m}{ }^{-2}$ $\mathrm{s}^{-1}$. The invasive seedlings in $\mathrm{P}+\mathrm{Q}+\mathrm{L}$ showed higher $\Phi_{\mathrm{PSII}}$ than those growing in $\mathrm{P}$ or $\mathrm{P}+\mathrm{Q}$ (Table 1), providing some support for hypothesis 1 . On average, $\Phi_{\mathrm{NPQ}}$ decreased and $\Phi_{\text {PSII }}$ increased as light availability increased (Tables $1, \mathrm{~S} 1$ ). $\Phi_{\mathrm{NPQ}}$ was lower in $\mathrm{P}+\mathrm{Q}+\mathrm{L}$ than in $\mathrm{P}$ and $\mathrm{P}+\mathrm{Q}\left(F_{2}=6.2\right.$, $P=0.005)$. In $\mathrm{HL}$, consistent with hypothesis 3 , competition and allelopathic effects led to more significant differences in $\Phi_{\mathrm{PSII}}$ than those observed in ML and LL (Fig. 1). Similar to $\Phi_{\mathrm{f}, \mathrm{D}}$ expressed as the area beneath the curve, $\Phi_{\mathrm{f}, \mathrm{D}}$ of $P$. serotina seedlings at $295 \mathrm{PPF}$ averaged across all treatments was highest in seedlings growing in LL, whereas those in ML and HL were significantly lower and did not differ from each other based on a Tukey's test (Table 1).

In $Q$. petraea, $\Phi_{\mathrm{f}, \mathrm{D}}$ did not differ among the light treatments (Table 1, S1, Fig. 2). On average, $Q$. petraea seedlings showed light acclimation of $\Phi_{\mathrm{NPQ}}$ and $\Phi_{\mathrm{PSII}}$ (Table 1). At the induction $\mathrm{PPF}=295 \mu \mathrm{mol} \mathrm{m} \mathrm{m}^{-2} \mathrm{~s}^{-1}, \Phi_{\mathrm{NPQ}}$ was significantly higher in LL than in HL, while the inverse was true for $\Phi_{\text {PSII }}$ (Table 1, S1). Consistent with hypothesis 1, competition and mulching treatments of $P$. serotina leaves had no effect on energy partitioning of native $Q$. petraea seedlings which showed lower plasticity in light energy partitioning compared with $P$. serotina.

\section{Leaf structure}

From the beginning to the end of the experiment, LMA of $P$. serotina increased by $30 \%$ and was not influenced by competition or mulching (Tables 2, S2). LMA did not differ between LL and ML, but increased by $29 \%$ in the HL treatment (Table S2).

LMA of Q. petraea increased by approximately $15 \%$ from June to July, then remained relatively unchanged through the remainder of the growing season (Tables 2, S2). Compared to LL, LMA of $Q$. petraea was $4 \%$ higher in ML and $19.5 \%$ higher in HL (Table S2). When all data were pooled across all the sampling dates, mulching with $P$. serotina leaves $(\mathrm{Q}+\mathrm{L})$ increased LMA of $Q$. petraea compared to seedlings grown in monoculture $(\mathrm{Q})$ which suggested a positive nutritional effect contrary to hypothesis 4 , but LMA of the interspecific competition and mulching treatment (Q+P + L) was similar to Q (Fig. 3d). Differences among the treatment combinations were further modified by light conditions of growth. LMA of $Q$. petraea was similar in all competition and mulching treatments in HL, but differences among treatments became more pronounced as light limitations increased (Table S2). 


\section{Prunus serotina}

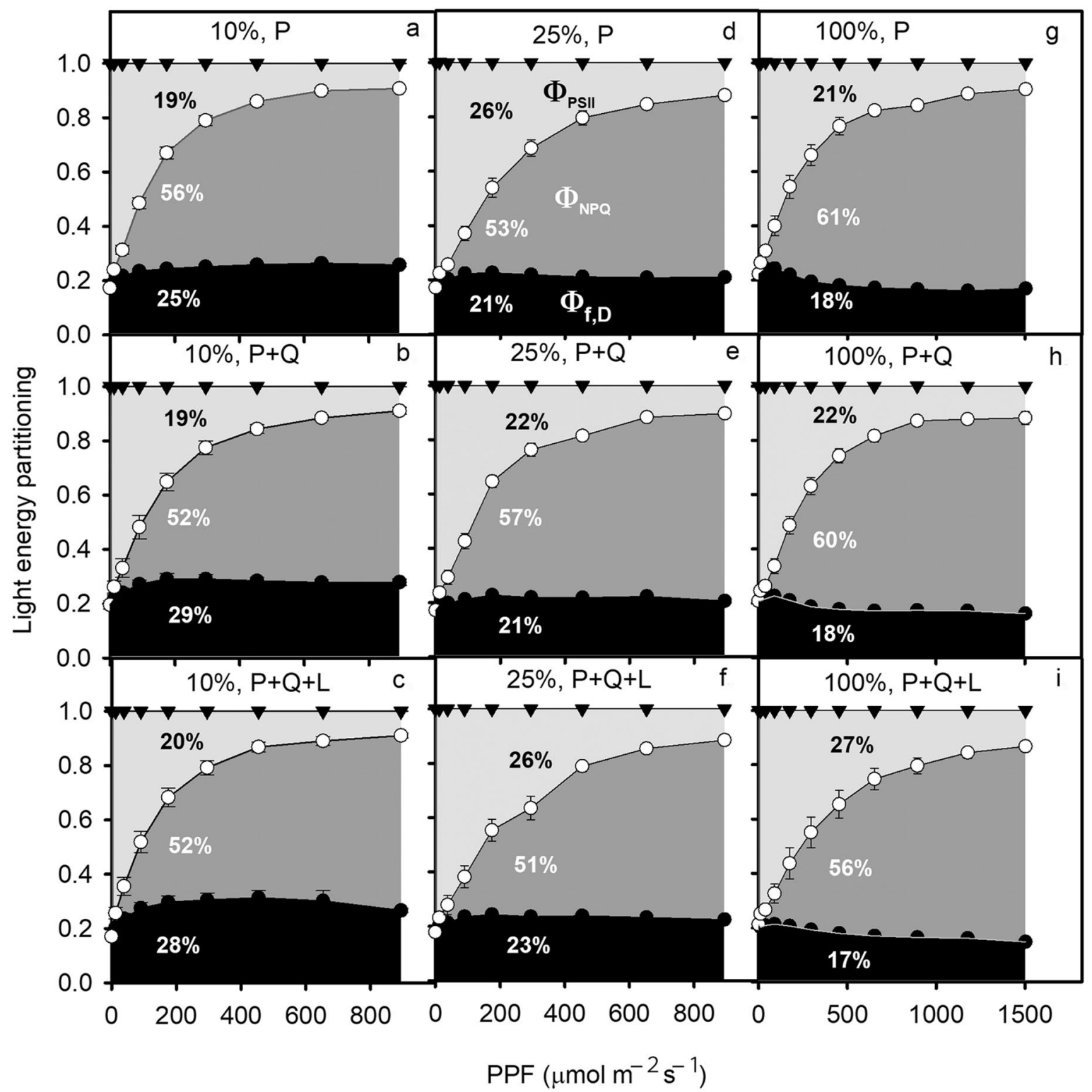

Fig. 1 Partitioning of light energy (shown as the percent area under the curve) absorbed by leaves of Prunus serotina seedlings acclimated to $10(\mathbf{a}-\mathbf{c}), 25(\mathbf{d}-\mathbf{f})$ or $100 \%$ of full sun light $(\mathbf{g}-\mathbf{i})$ and growing in one of three combinations: $\mathrm{P}$, three $P$. serotina seedlings; $\mathrm{P}+\mathrm{Q}$, six $P$. serotina and three Quercus petraea seedlings; $\mathrm{P}+\mathrm{Q}+\mathrm{L}$, six $P$. serotina and three $Q$. petraea seedlings with mulching with $P$. serotina leaves; $\Phi_{\mathrm{PSII}}$, quantum yield of PSII photochemistry $\Phi_{\mathrm{PSII}} ; \Phi_{\mathrm{NPQ}}$,

\section{Photosynthetic capacity}

In $P$. serotina, $\mathrm{A}_{\max }$ expressed per gram leaf dry mass did not change considerably from month to month and was $28 \mathrm{nmol} \mathrm{g}^{-1} \mathrm{~s}^{-1}$ on average. In contrast, $\mathrm{A}_{\max }$ of $Q$. petraea decreased progressively from June to September from 62 to $32 \mathrm{nmol} \mathrm{g}^{-1} \mathrm{~s}^{-1}$ and its mean seasonal value was $47 \mathrm{nmol}$ quantum yield of $\Delta \mathrm{pH}$ - and xanthophyll-regulated thermal energy dissipation; $\Phi_{f, D}$, quantum yield of constitutive fluorescence and thermal energy dissipation. Triangles $-\Phi_{\mathrm{PSII}}+\Phi_{\mathrm{NPQ}}+\Phi_{\mathrm{f}, \mathrm{D}}$; white circles $-\Phi_{\mathrm{NPQ}}+\Phi_{\mathrm{f}, \mathrm{D}}$; black circles $-\Phi_{\mathrm{f}, \mathrm{D}}$ (mean $\left.\pm \mathrm{SE}\right)$. Light green area- a fraction of energy transferred to photochemistry; dark green area-energy dissipated as heat; black area-constitutive energy losses ( $n=6$ seedlings per species, light treatment and combination)

$\mathrm{g}^{-1} \mathrm{~s}^{-1}$ (Tables $\left.2, \mathrm{~S} 3, \mathrm{~S} 4\right)$. In $P$. serotina, $\mathrm{A}_{\max }$ was twofold higher in HL than in LL and this was accompanied by twofold increase in $\mathrm{R}_{\mathrm{d}}$ (Table S3). In $Q$. petraea, $\mathrm{A}_{\max }$ was 2.5-fold higher in HL than in LL, and $\mathrm{R}_{\mathrm{d}}$ increased by $30 \%$ (Table S4).

When the mean values calculated across all the sampling dates were compared, $\mathrm{A}_{\max }$ in $\mathrm{P}+\mathrm{Q}+\mathrm{L}$ decreased compared 


\section{Quercus petraea}

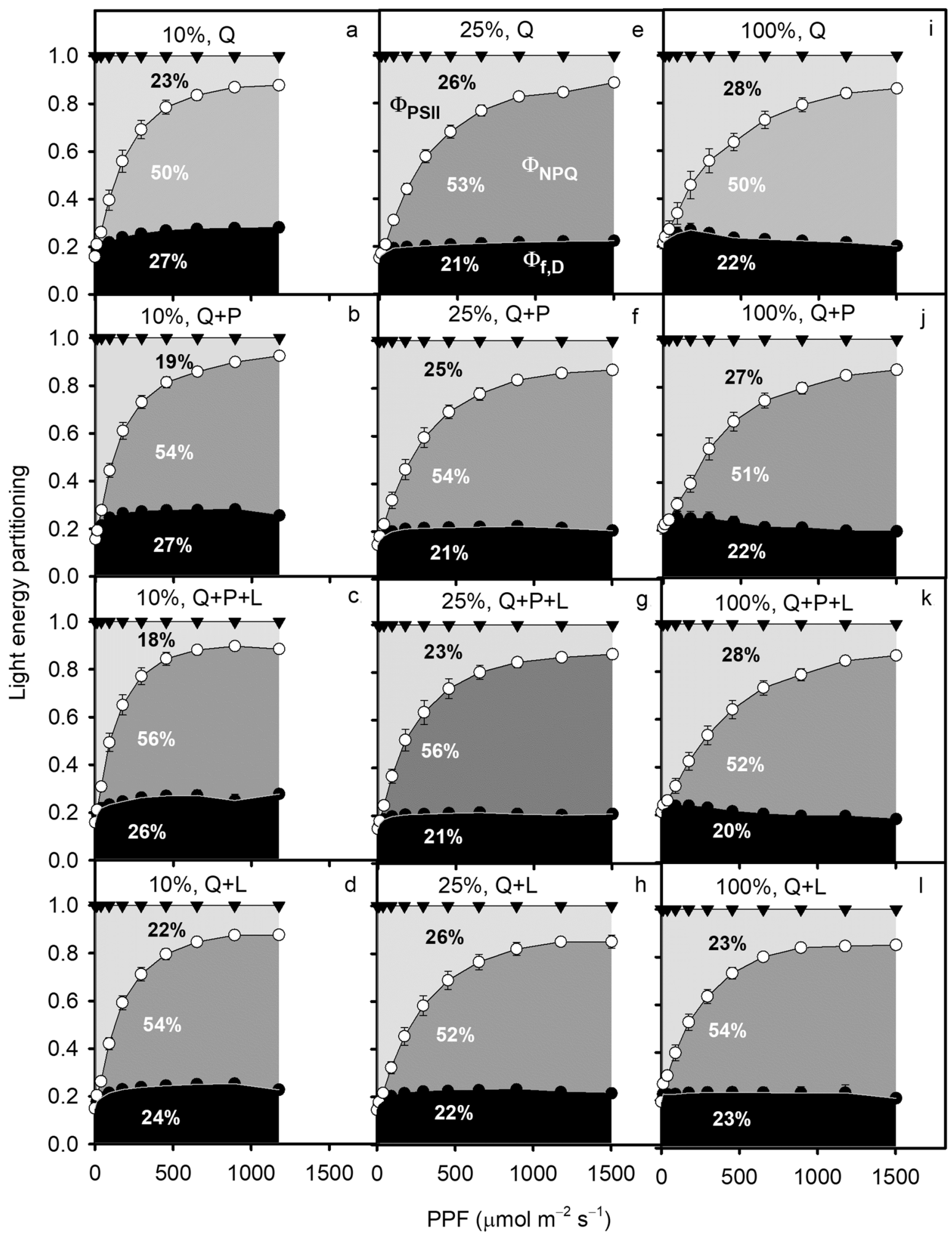

Fig. 2 Partitioning of light energy absorbed by leaves of Quercus petraea seedlings acclimated to $10(\mathbf{a}-\mathbf{c}, \mathbf{d}), 25(\mathbf{d}-\mathbf{g})$ or $100 \%$ of full sun light $(\mathbf{g}-\mathbf{j})$ and growing in one of four combinations: $\mathrm{Q}$, three $Q$. petraea seedlings; $\mathrm{Q}+\mathrm{P}$, three Quercus petraea seedlings and six $P$. serotina seedlings; $\mathrm{Q}+\mathrm{P}+\mathrm{L}$, three Quercus petraea seedlings and six $P$. serotina with mulching with $P$. serotina leaves; $\mathrm{Q}+\mathrm{L}$, three $Q$. petraea seedlings with mulching. For the further explanations, see Fig. 1 $(n=6)$ 
Table 2 Analysis of variance in split-split plot design of block, date of sampling, light and treatment combinations and interactions on leaf mass to area ratio (LMA, $\mathrm{g} \mathrm{m}^{-2}$ ), net $\mathrm{CO}_{2}$ assimilation rate at saturating light $\left(\mathrm{A}_{\max }, \mathrm{nmol} \mathrm{g}^{-1}\right.$ $\left.\mathrm{s}^{-1}\right)$, leaf dark respiration $\left(\mathrm{R}_{\mathrm{d}}\right.$, nmol g $\mathrm{g}^{-1} \mathrm{~s}^{-1}$ ), photosynthetic nitrogen use efficiency (PNUE, $\mu \mathrm{mol} \mathrm{CO} \mathrm{Col} \mathrm{N}^{-1}$, water use efficiency (WUE, $\mu \mathrm{mol} \mathrm{CO} \mathrm{CO}_{2}$ mmol $\mathrm{H}_{2} \mathrm{O}^{-1}$ ), and respiratory costs of photosynthesis $\left(\mathrm{R}_{\mathrm{d}} /\right.$ $\left.\mathrm{A}_{\max }\right)$ of Prunus serotina and Quercus petraea seedlings. The block effect was not significant, therefore the effects of block and of interactions with block are omitted

\begin{tabular}{|c|c|c|c|c|c|c|}
\hline \multirow[t]{2}{*}{ Effect } & \multicolumn{3}{|c|}{ Prunus serotina } & \multicolumn{3}{|c|}{ Quercus petraea } \\
\hline & $d f$ & $F$ & $P$ & $d f$ & $F$ & $P$ \\
\hline \multicolumn{7}{|l|}{ LMA } \\
\hline Date of sampling & 3 & 49.32 & $<0.001$ & 3 & 12.80 & 0.007 \\
\hline Light & 2 & 94.95 & $<0.001$ & 2 & 122.32 & $<0.001$ \\
\hline Date of sampling $\times$ light & 6 & 6.49 & 0.001 & 6 & 1.94 & 0.135 \\
\hline Combination & 1 & 0.22 & 0.644 & 2 & 5.54 & 0.007 \\
\hline Date $\times$ combination & 3 & 1.91 & 0.155 & 6 & 0.781 & 0.589 \\
\hline Light $\times$ combination & 2 & 4.38 & 0.024 & 4 & 3.05 & 0.026 \\
\hline Date $\times$ light $\times$ combination & 6 & 0.81 & 0.575 & 12 & 0.657 & 0.783 \\
\hline \multicolumn{7}{|l|}{$A_{\text {net }}$} \\
\hline Date of sampling & 3 & 1.78 & 0.251 & 3 & 15.60 & 0.003 \\
\hline Light & 2 & 25.59 & 0.005 & 2 & 131.28 & $<0.001$ \\
\hline Date of sampling $\times$ light & 6 & 0.31 & 0.748 & 6 & 3.76 & 0.016 \\
\hline Combination & 1 & 10.01 & 0.004 & 2 & 4.05 & 0.024 \\
\hline Date $\times$ combination & 3 & 2.65 & 0.072 & 6 & 1.34 & 0.259 \\
\hline Light $\times$ combination & 2 & 2.99 & 0.069 & 4 & 2.58 & 0.049 \\
\hline Date $\times$ light $\times$ combination & 6 & 0.94 & 0.484 & 12 & 0.97 & 0.493 \\
\hline \multicolumn{7}{|l|}{$\mathrm{R}_{\mathrm{d}}$} \\
\hline Date of sampling & 3 & 6.37 & 0.030 & 3 & 0.290 & 0.832 \\
\hline Light & 2 & 26.84 & $<0.001$ & 2 & 13.72 & 0.006 \\
\hline Date of sampling $\times$ light & 6 & 3.30 & 0.026 & 6 & 2.24 & 0.093 \\
\hline Combination & 1 & 0.35 & 0.561 & 2 & 6.37 & 0.004 \\
\hline Date $\times$ combination & 3 & 0.87 & 0.473 & 6 & 0.63 & 0.451 \\
\hline Light $\times$ combination & 2 & 0.39 & 0.679 & 4 & 0.937 & 0.451 \\
\hline Date $\times$ light $\times$ combination & 6 & 1.35 & 0.276 & 12 & 1.20 & 0.315 \\
\hline \multicolumn{7}{|l|}{ PNUE } \\
\hline Date of sampling & 3 & 3.79 & 0.090 & 3 & 57.25 & $<0.001$ \\
\hline Light & 2 & 21.36 & 0.002 & 2 & 84.65 & $<0.001$ \\
\hline Date of sampling $\times$ light & 6 & 3.84 & 0.015 & 6 & 4.77 & 0.006 \\
\hline Combination & 1 & 11.35 & 0.003 & 2 & 2.77 & 0.072 \\
\hline Date $\times$ combination & 3 & 2.53 & 0.081 & 6 & 0.66 & 0.685 \\
\hline Light $\times$ combination & 2 & 1.54 & 0.234 & 4 & 3.24 & 0.020 \\
\hline Date $\times$ light $\times$ combination & 6 & 0.17 & 0.982 & 12 & 0.58 & 0.844 \\
\hline \multicolumn{7}{|l|}{ WUE } \\
\hline Date of sampling & 3 & 21.42 & 0.001 & 3 & 14.19 & 0.005 \\
\hline Light & 2 & 13.89 & 0.006 & 2 & 43.37 & $<0.001$ \\
\hline Date of sampling $\times$ light & 6 & 3.50 & 0.020 & 6 & 3.97 & 0.013 \\
\hline Combination & 1 & 1.12 & 0.300 & 2 & 6.31 & 0.004 \\
\hline Date $\times$ combination & 3 & 0.54 & 0.658 & 6 & 1.15 & 0.347 \\
\hline Light $\times$ combination & 2 & 0.68 & 0.515 & 4 & 1.94 & 0.119 \\
\hline Date $\times$ light $\times$ combination & 6 & 2.50 & 0.510 & 12 & 1.56 & 0.137 \\
\hline \multicolumn{7}{|l|}{$\mathrm{R}_{\mathrm{d}} / \mathrm{A}_{\max }$} \\
\hline Date of sampling & 3 & 1.74 & 0.258 & 3 & 3.28 & 0.109 \\
\hline Light & 2 & 0.95 & 0.443 & 2 & 44.23 & $<0.001$ \\
\hline Date of sampling $\times$ light & 6 & 2.28 & 0.088 & 6 & 4.10 & 0.011 \\
\hline Combination & 1 & 3.56 & 0.071 & 2 & 0.36 & 0.698 \\
\hline Date $\times$ combination & 3 & 0.27 & 0.849 & 6 & 0.48 & 0.822 \\
\hline Light $\times$ combination & 2 & 1.15 & 0.334 & 4 & 4.69 & 0.003 \\
\hline Date $\times$ light $\times$ combination & 6 & 0.37 & 0.894 & 12 & 0.99 & 0.470 \\
\hline
\end{tabular}


Fig. 3 Left hand panels The mean $( \pm$ SE) values of a leaf mass-to-area ratio (LMA), b maximum net $\mathrm{CO}_{2}$ assimilation rate expressed per leaf dry mass $\left(\mathrm{A}_{\text {max }}\right)$, and $\mathbf{c}$ dark respiration rate per unit dry mass $\left(\mathrm{R}_{\mathrm{d}}\right)$ of $P$. serotina seedling monocultures (P) or six P. serotina seedlings in competition with three $Q$. petraea seedlings with mulching $(\mathrm{P}+\mathrm{Q}+\mathrm{L})$. Right hand panels The mean $( \pm \mathrm{SE})$ values of $\mathbf{d}$ $L M A$, e $\mathrm{A}_{\max }$, and $\mathbf{f} \mathrm{R}_{\mathrm{d}}$ of $Q$. petraea seedling monocultures $(\mathrm{Q})$, three $Q$. petraea seedlings with mulching $(\mathrm{Q}+\mathrm{L})$, or three $Q$. petraea seedlings in competition with six $P$. serotina seedlings with mulching $(\mathrm{Q}+\mathrm{P}+\mathrm{L})$. All data were pooled across June, August, September and October. The $F$ values with the number of degrees of freedom in lower index and probability obtained from ANOVA are shown. $0.05>P^{*} \geq 0.01,0.01>P^{* *} \geq$ $0.001, P^{* * *}<0.001(n=36)$

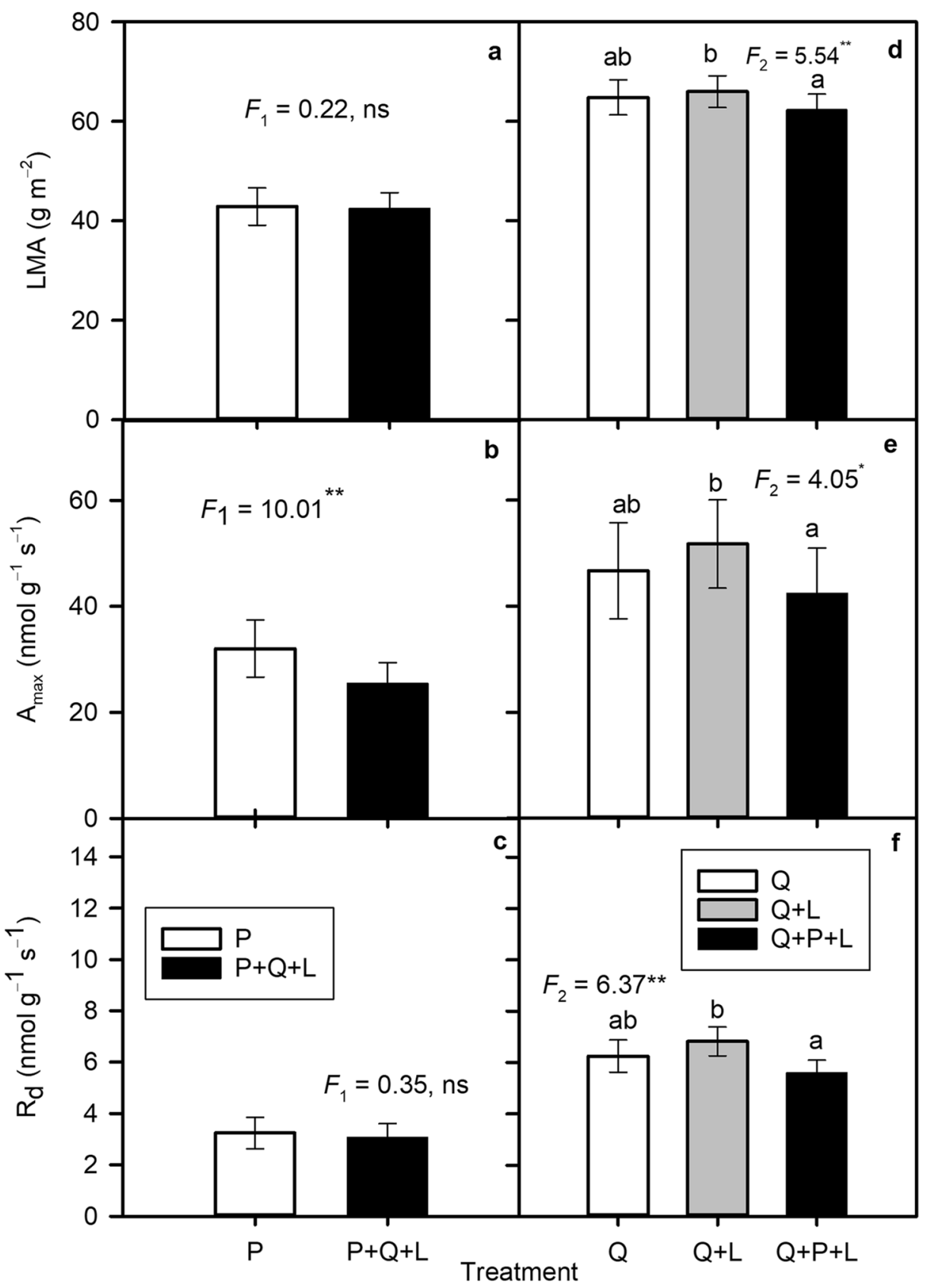

with $\mathrm{P}$, while $\mathrm{R}_{\mathrm{d}}$ remained stable, rejecting hypothesis 2 (Table 2; Fig. 3b, c). The $\mathrm{Q}+\mathrm{L}$ treatment exhibited the highest rates of both $A_{\max }$ and $R_{d}$, while the $Q+P+L$ treatment was similar to the monoculture (Tables S3, S4, Fig. 3e, f). Additionally, the light $\times$ treatment combination interaction influenced $\mathrm{A}_{\max }$ of Quercus, indicating a positive effect of mulching that was the most significant in LL (Table S4).

In contrast to $\mathrm{A}_{\max }$, when $\mathrm{A}_{\text {crown }}$ was calculated for individual seedlings, it was higher on average in $P$. serotina than in $Q$. petraea (Tables S5, S6). Thus, while hypothesis 2 was rejected for $P$. serotina leaf level traits, the invasive species did have enhanced photosynthetic capacity at the crown level. $A_{\text {crown }}$ of $P$. serotina increased abruptly in September (DOY - day of year 269) (due to the high leaf mass and area per seedling), whereas $\mathrm{A}_{\text {crown }}$ of $Q$. petraea did not change significantly across the season. The most striking difference between the two species was their response to higher levels of light availability: invasive $P$. serotina increased $\mathrm{A}_{\text {crown }}$ 40-fold from LL to $\mathrm{HL}$, while native $Q$. petraea only increased fourfold (Table S6). 
Fig. 4 Left hand panels The mean $( \pm S E)$ values of a photosynthetic water use efficiency (WUE) and b photosynthetic nitrogen use efficiency (PNUE) of $P$. serotina seedling monocultures (P) or six $P$. serotina seedlings in competition with three $Q$. petraea seedlings with mulching $(\mathrm{P}+\mathrm{Q}+\mathrm{L})$. Right hand panels $\mathbf{c}$ WUE and $\mathbf{d}$ PNUE of $Q$. petraea seedling monocultures $(\mathrm{Q})$, three $Q$. petraea seedlings with mulching $(\mathrm{Q}+\mathrm{L})$, or three $Q$. petraea seedlings in competition with six $P$. serotina seedlings with mulching $(\mathrm{Q}+\mathrm{P}+\mathrm{L})$. All data were pooled across June, August, September and October. The $F$ values with the number of degrees of freedom in lower index and probability obtained from ANOVA are shown. $0.05>P^{*} \geq 0.01,0.01>P^{* *} \geq$ $0.001, P^{* * *}<0.001(n=36)$

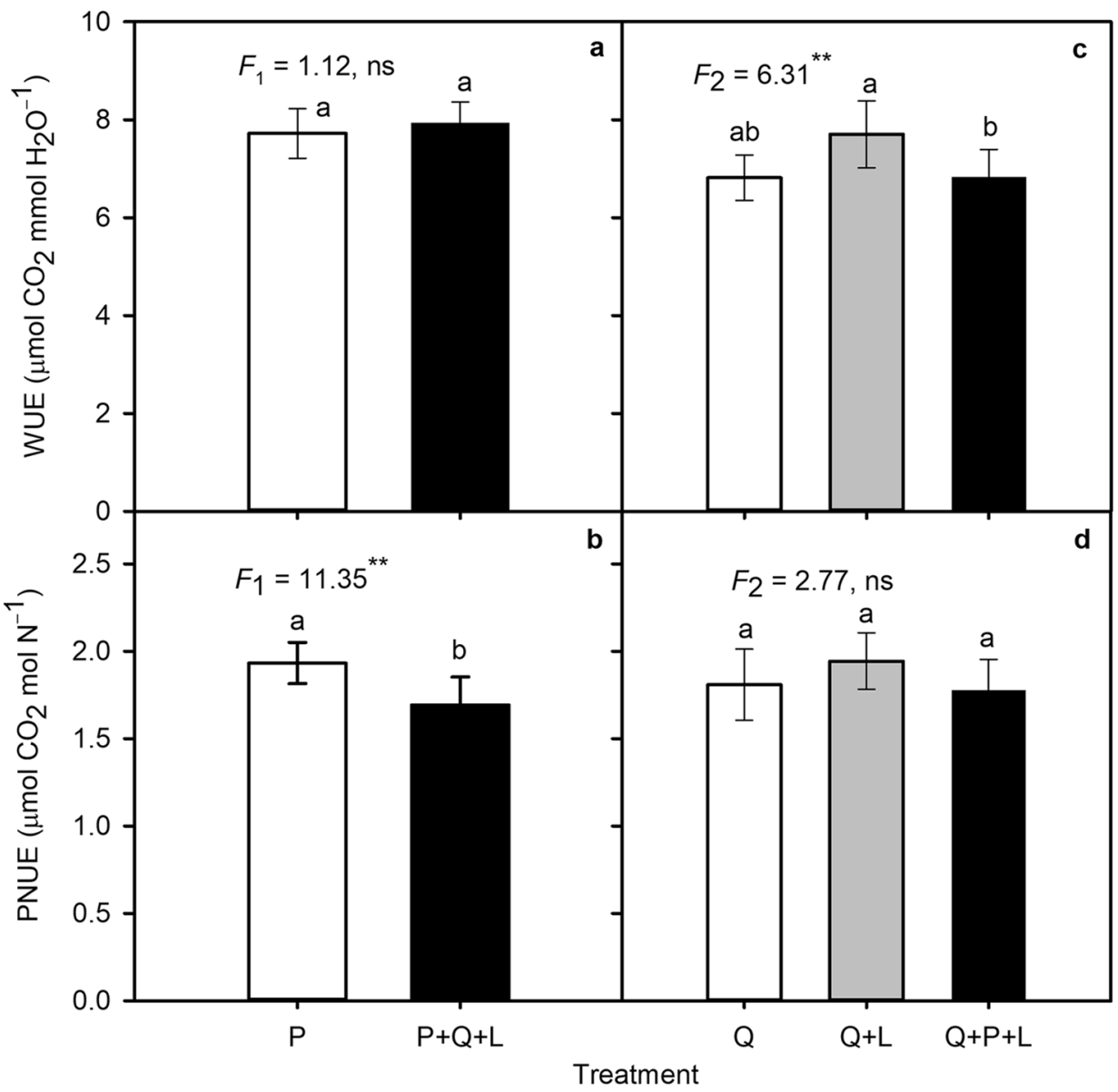

\section{Photosynthetic efficiency}

In both species, photosynthetic nitrogen use efficiency (PNUE) decreased throughout the growing season, but was always higher in $P$. serotina than in $Q$. petraea, consistent with hypothesis 2 . Both invasive $P$. serotina and native $Q$. petraea increased PNUE on average in ML and HL compared with LL (Tables 2, S7, S8). P. serotina was able to enhance PNUE by $54 \%$ and $Q$. petraea by $83 \%$ in HL compared with LL. P+Q+L showed a $24 \%$ lower PNUE compared to P (Table S7, Fig. 4b), while PNUE of Q. petraea was similar in all competition and mulching treatments (Table 2; Fig. 4d). Leaf nitrogen concentration decreased with increasing light and LMA $(Q$. petraea LL $30.12 \pm 0.60$ and HL $27.33 \pm 0.74 \mathrm{mg} \mathrm{g}^{-1}$; P. serotina LL $33.19 \pm 0.91$ and HL $\left.29.33 \pm 1.19 \mathrm{mg} \mathrm{g}^{-1}\right)$. In $Q$. petraea, the highest leaf nitrogen concentration was in $\mathrm{Q}+\mathrm{L}(30.69 \pm 0.74 \mathrm{mg}$ $\mathrm{g}^{-1}$ ), and in P. serotina it decreased from $33.96 \pm 0.89$ in $\mathrm{P}$ to $30.53 \pm 1.11 \mathrm{mg} \mathrm{g}^{-1}$ in $\mathrm{P}+\mathrm{Q}+\mathrm{L}$.

Photosynthetic water use efficiency (WUE) in both species depended on date of sampling, light and, in Q. petraea, on treatment combination (Table 2). On average in P. serotina seedlings, WUE increased from May (DOY 146) to
September (DOY 269) and the opposite trend was observed in $Q$. petraea (Tables S7, S8). In both species, WUE was greatest in HL and declined as light became more limiting. Interspecific competition and mulching treatments did not affect WUE of $P$. serotina (Table S7, Fig. 4a), while WUE increased significantly in the $\mathrm{Q}+\mathrm{L}$ treatment as compared to $\mathrm{Q}$ and $\mathrm{Q}+\mathrm{P}+\mathrm{L}$ (Table S8, Fig. 4c).

The overall respiration costs of photosynthesis $\left(\mathrm{R}_{\mathrm{d}} / \mathrm{A}_{\max }\right)$ were higher in $Q$. petraea compared with $P$. serotina $\left(\mathrm{R}_{\mathrm{d}} /\right.$ $\mathrm{A}_{\max }=0.17 \pm 0.01$ and $0.12 \pm 0.01$, respectively), supporting hypothesis 2 . This was true throughout the growing season, with differences between species being most extreme at the end of the growing season. Date of sampling, light environment and treatment combination did not significantly affect $\mathrm{R}_{\mathrm{d}} / \mathrm{A}_{\max }$ in P. serotina (Table 2). In contrast, light environment significantly affected respiration costs of photosynthesis in $Q$. petraea, which decreased as light availability increased $(\mathrm{LL}=0.23 \pm 0.02, \mathrm{ML}=0.17 \pm 0.02$, $\mathrm{HL}=0.12 \pm 0.01)$. In $\mathrm{ML}, \mathrm{R}_{\mathrm{d}} / \mathrm{A}_{\max }$ was similar in $\mathrm{Q}$ and $\mathrm{Q}+\mathrm{L}$, and lowest in $\mathrm{Q}+\mathrm{P}+\mathrm{L}(0.17 \pm 0.03,0.21 \pm 0.04$ and $0.14 \pm 0.03$, respectively). 


\section{Relative growth rate and biomass allocation to foliage}

Mean initial dry mass (DM) of P. serotina and Q. petraea organs were: roots $0.190 \pm 0.052,0.357 \pm 0.031$, shoots: $0.069 \pm 0.005,0.129 \pm 0.020$, and leaves: $0.034 \pm 0.003$, $0.415 \pm 0.052 \mathrm{~g}$, respectively $(n=10, n$-number of seedlings). Initial total seedling DM of $Q$. petraea was $0.901 \pm 0.099$ and $P$. serotina $0.293 \pm 0.056$ g. $P$. serotina had higher RGR than $Q$. petraea $(0.133 \pm 0.004$ and $0.09 \pm 0.004 \mathrm{~g}$ total $\mathrm{DM}$ day $^{-1}$, respectively, all data pooled, $\left.F_{1}=48.6, P<0.0001\right)$ and the differences between the species increased as light availability increased: compared to $Q$. petraea, RGR of $P$. serotina 1.8 -fold higher in LL, 2.1-fold higher in ML, and 2.3-fold higher in HL, providing support for hypotheses 3 and 5 (Figs. 5, 6). RGR of $Q$. petraea did not differ significantly among competition and mulching treatments (Fig. 5b), while RGR of $\mathrm{P}+\mathrm{Q}+\mathrm{L}$ in low light was greater than that of $\mathrm{P}$ and $\mathrm{P}+\mathrm{Q}$ (Fig. 5a). Leaf area ratio $(L A R)$ decreased and total leaf area $\left(A_{L}\right)$ increased with light for both species, but more significantly for the invasive than native species (Fig. 5c-f). In LL, RGR, LAR and $A_{L}$ were highest in $P+Q$, and in HL, RGR and $A_{L}$ were lower in $\mathrm{P}+\mathrm{Q}$ than in $\mathrm{P}+\mathrm{Q}+\mathrm{L}$ (Fig. 1a, c, e).
Fig. 5 Relative growth rate (RGR), leaf area ratio (LAR), and total leaf area $\left(\mathrm{A}_{\mathrm{L}}\right)$ of Prunus serotina $(\mathbf{a}, \mathbf{c}, \mathbf{e})$ and Quercus petraea $(\mathbf{b}, \mathbf{d}, \mathbf{f})$ seedlings which were grown in one of three light treatment $(10,25$ or $100 \%$ of full sun light) and five combinations: $\mathrm{P}, \mathrm{Q}, \mathrm{Q}+\mathrm{L}$, $\mathrm{P}+\mathrm{Q}(\mathrm{Q}+\mathrm{P})$ or $\mathrm{P}+\mathrm{Q}+\mathrm{L}$ $(\mathrm{Q}+\mathrm{P}+\mathrm{L})$. The $F$ values with the number of degrees of freedom in lower index and probability obtained from twofactorial analysis of variance with light, combination and interaction are shown. The same capital letters indicate that the mean values do not significantly differ among light treatments. The same small letters indicate that the mean values are not significantly different between combination within a light treatment in Least Significant Difference test. $0.05>P^{*} \geq$ $0.01,0.01>P^{* *} \geq 0.001, P^{* * *}$ $<0.001$ (Q. petraea $n=76, P$. serotina $n=63$ )

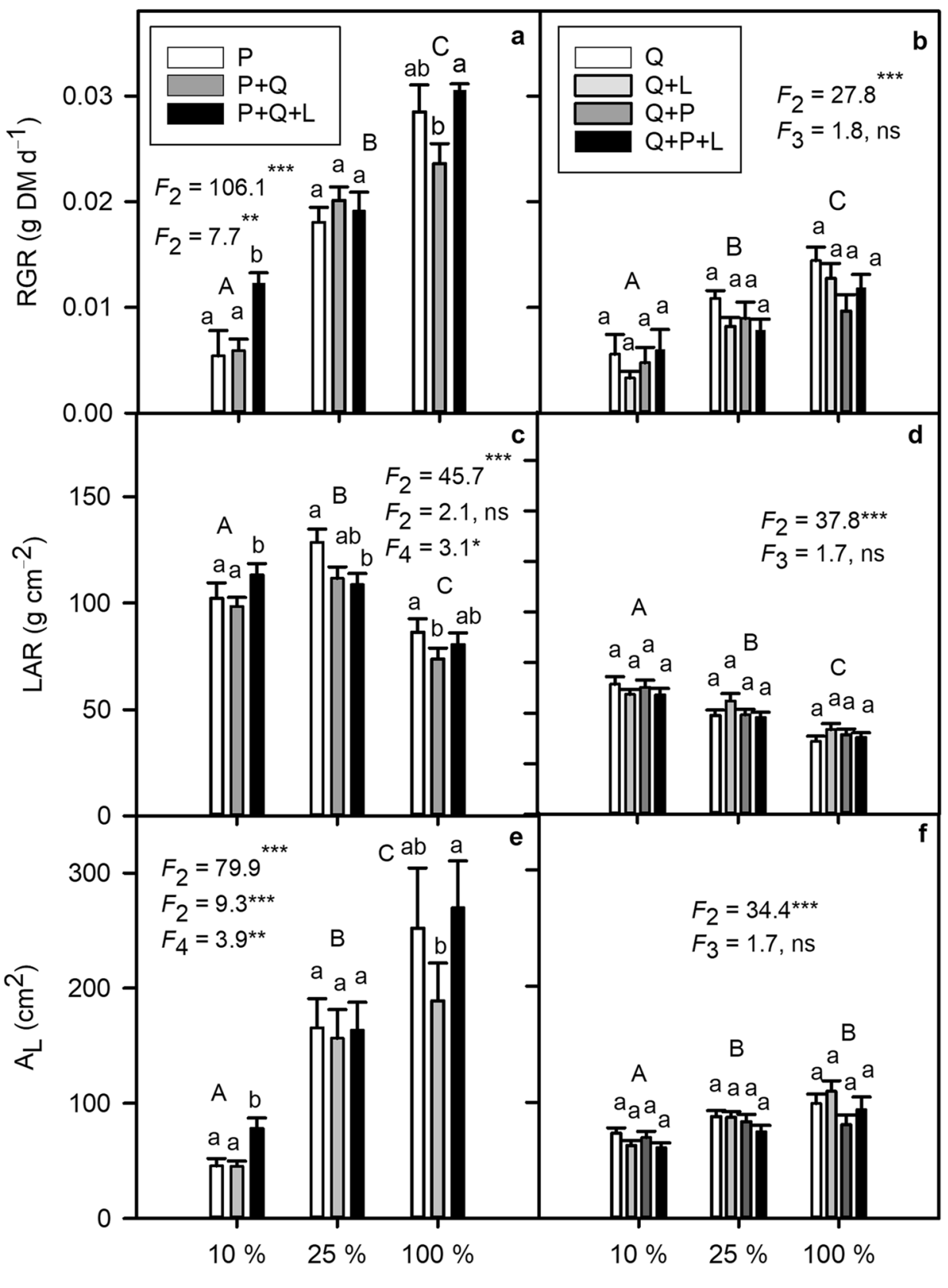

Light treatment 


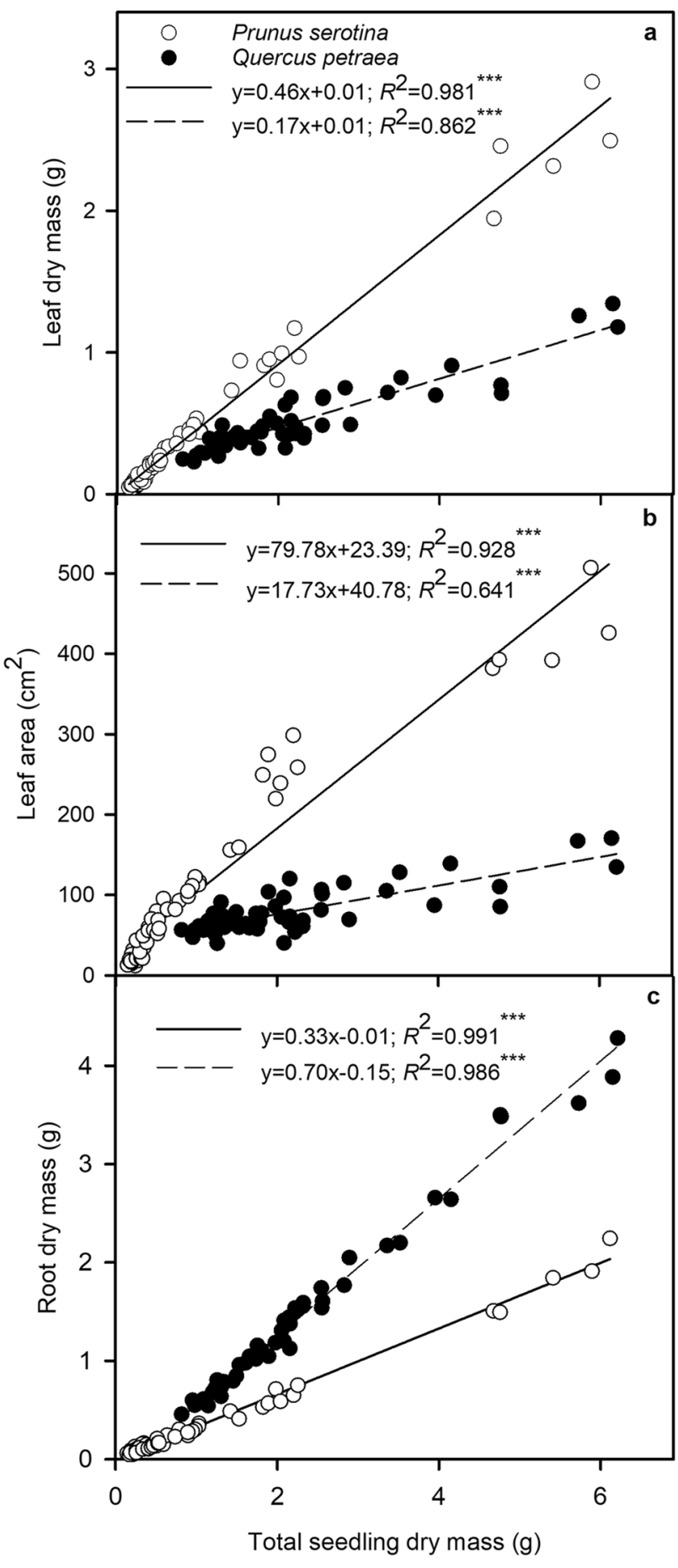

Fig. 6 Linear regressions between a leaf dry mass, $\mathbf{b}$ leaf area, and $\mathbf{c}$ root dry mass and total seedling dry mass. The seedlings were grown in one of three light treatment $(10,25$ or $100 \%$ of full sun light $)$ and three combination treatments $[\mathrm{P}, \mathrm{Q}$ or $\mathrm{P}+\mathrm{Q}+\mathrm{L}(\mathrm{Q}+\mathrm{P}+\mathrm{L})]$. Each point represents the mean value of three seedlings per species per pot ( $n=216$ seedlings per species)
The linear relationship between $P$. serotina total seedling dry mass vs. leaf dry mass had over a two-fold steeper slope than for $Q$. petraea seedlings (Fig. 6a), providing support for hypothesis 5 . The slope of the relationship between the total seedling dry mass vs. leaf area was more than fourfold steeper for $P$. serotina compared with the slope for $Q$. petraea (Fig. 6b). Alternatively, the slope of the relationship between total seedling dry mass vs. root dry mass was significantly steeper for $Q$. petraea than for P. serotina (Fig. 6c).

\section{Discussion}

\section{Leaf absorbed light energy partitioning}

Competition between invasive $P$. serotina and native $Q$. petraea has been observed in situ under the canopy of Scots pine forests in Europe. We simulated this competition and potential allelochemical interspecific interactions under different controlled light environments. This study complements and adds to prior studies comparing morphological and physiological traits of invasive and native species (e.g. Boyd et al. 2009; Funk 2008; Harrington et al. 1989; Mangla et al. 2011; Molina-Montenegro et al. 2012; Leishman et al. 2007; van Kleunen et al. 2010), and focuses on species responses to seasonality, light environment, competition, and allelopathic effects from mulching with $P$. serotina leaves. Our results show that the acclimation of leaf absorbed light energy partitioning is more strongly affected by light environment than by competition and allelopathy (Tables 1, S1; Figs. 1,2). Here, we expand on prior studies by focusing on interspecific competition for light and its effect on partitioning of light energy into three competing processes: $\Phi_{\mathrm{PSI}}, \Phi_{\mathrm{NPQ}}$, and $\Phi_{\mathrm{f}, \mathrm{D}}$. It is worth noting that $P$. serotina increased $\Phi_{\mathrm{NPQ}}$ and $\Phi_{\mathrm{PSII}}$ markedly at the expense of $\Phi_{\mathrm{f}, \mathrm{D}}$ when growing in $\mathrm{ML}$ and HL compared with LL, especially when in competition with $Q$. petraea with mulching (Fig. 1c, f, i). This response of invasive $P$. serotina to light can be regarded as the 'Oskar Syndrome' at the bioenergetics level. The 'Oskar Syndrome' is a dynamic increase in the growth of a shadeacclimated plant following exposure to a brighter light environment (Closset-Kopp et al. 2007, 2011). Higher amounts of leaf absorbed light energy translocated to $\Phi_{\text {PSII }}$ can contribute to an increase in growth under optimal light conditions. $Q$. petraea also increased $\Phi_{\mathrm{NPQ}}$ and $\Phi_{\mathrm{PSII}}$ in HL compared with LL, but the differences between the light treatments were less extreme than those observed for P. serotina (Fig. 2). For the first time, we have shown that higher plasticity of light energy partitioning can give an important competitive advantage to invasive over native species (Tables 1, S1, Figs. 1, 2). Our results also add to 
the body of evidence showing higher morphological plasticity of invasive compared to native species in response to light (Figs. 5, 6; Daehler 2003; Funk 2008; MolinaMontenegro 2012). In contrast to our results, DemmigAdams and Adams (1996) observed a similar conversion state of the xanthophyll cycle and a similar level of energy dissipation for a given degree of light stress, independent of species or light stress conditions.

Interestingly, in our study, at PPF $=295 \mu \mathrm{mol} \mathrm{m}^{-2} \mathrm{~s}^{-1}$, $P$. serotina increased $\Phi_{\mathrm{PSII}}$ growing in the presence of its competitor with mulching $(\mathrm{P}+\mathrm{Q}+\mathrm{L}$ vs. $\mathrm{P})$. Together with a lack of difference between $\mathrm{P}$ and $\mathrm{P}+\mathrm{Q}$ these results suggest that there was a positive allelopathic effect of mulching, or a positive synergistic effect of interspecific competition and allelopathy on $P$. serotina $\Phi_{\mathrm{PSII}}$. This is in agreement with hypothesis 1 , suggesting that invasive species can enhance photosynthetic performance by transferring more energy to photochemistry when growing in the presence of a competitor (Tables 1, S1). An increase in $\Phi_{\mathrm{PSII}}$ may have occured due to higher availability and allocation of nitrogen to photochemistry in $\mathrm{P}+\mathrm{Q}+\mathrm{L}$. However, our results do not support hypothesis 2 since $A_{\max }$ was lower in $P+Q+L$ compared to $P$, suggesting that energy was dissipated as heat or used in non-photosynthetic processes (Niyogi 1999). Nevertheless, our results suggest that the responsiveness of invasive $P$. serotina to light and competition with or without mulching is more dynamic than that of native Q. petraea (Tables $1, \mathrm{~S} 1$, Fig. 5). Compared to observed levels of $\Phi_{\mathrm{NPQ}}$ obtained in our study (P. serotina from 52 to $61 \%, Q$. petraea from 50 to $56 \%$ ), leaves of grapevines growing in full sunlight have been found to dissipate up to $75 \%$ of total absorbed daily radiation via $\Delta \mathrm{pH}$ - and xanthophyll-regulated thermal dissipation (Hendrickson et al. 2004). Compared with our experiment, higher values of $\Phi_{\mathrm{NPQ}}$ resulted from growing grapevines in a greenhouse. Another study observed that under drought stress, $\Phi_{\mathrm{NPQ}}$ can be as high as $92 \%$ of total absorbed radiation (Flexas and Medrano 2002). P. serotina and $Q$. petraea in our study increased $\Phi_{\mathrm{PSII}}$ in ML and HL compared with LL at the expense of $\Phi_{f, D}$. The stress caused by a deficit of light in the LL treatment enhanced $\Phi_{\mathrm{f}, \mathrm{D}}$ and reduced $\Phi_{\mathrm{PSII}}$ compared with HL.

\section{Leaf structure}

$P$. serotina had lower LMA than $Q$. petraea independent of sampling date, light environment or treatment combination (Table S4, Fig. 1a, d). The global leaf economic spectrum indicates that species with lower LMA have higher photosynthetic capacities (Wright et al. 2004). Interestingly, in our experiment the mean LMA value of $P$. serotina $(43 \pm 1 \mathrm{~g}$ $\mathrm{m}^{-2}$ ) was lower than LMA of this species in Minnesota, where it naturally occurs $\left(48 \pm 3 \mathrm{~g} \mathrm{~m}^{-2}\right.$ ) (Sendall and Reich
2013). This observation supports the hypothesis that invasive $P$. serotina is able to decrease LMA in its introduced geographical range. In our study, both species increased LMA in HL compared with LL and ML, but contrasting with the results of Leishman et al. (2010), they did not differ substantially in the magnitude of this increase. Pattison et al. (1998) showed that five invasive and four native species grown in the shade had lower LMA than those grown in full sun, while other studies have shown that $P$. serotina juveniles growing in full sun have approximately threefold higher LMA than in the understory (Harrington et al. 1989; Sendall and Reich 2013). Leaf structural changes reflected by LMA, together with biochemical mechanisms of excess energy dissipation, allow plants to use light more efficiently for photosynthesis and protect the photosynthetic apparatus against excess energy (Ellsworth and Reich 1992; Niinemets et al. 1998).

Photosynthetic and leaf structural responses of $Q$. petraea and $P$. serotina to different light environments suggest that they are functionally similar. Both species increased $A_{\text {max }}$, PNUE and LMA with increasing light. However, high light availability favoured $P$. serotina over $Q$. petraea (Tables $\mathrm{S} 2$, S6, Fig. 5). This is in accordance with Firn et al. (2010) who found that the ability of invading grasses to suppress natives was greater under higher resource supply.

In our study, LMA and $A_{\max }$ were lower for $\mathrm{Q}+\mathrm{P}+\mathrm{L}$ when compared with $\mathrm{Q}+\mathrm{L}$ indicating a significant effect of interspecific competition on $Q$. petraea leaf structure and photosynthesis when the competition occurs with mulching (Tables S2, S4 Fig. 3d, e). In contrast to our results, Kozovits et al. (2005) found that the competition between two co-occurring native species in Europe Fagus sylvatica and Picea abies, was not associated with changes in LMA or carbon gain efficiency. This difference may result from more intense interspecific competition between the invasive and native species enhanced by allelopathic or nutritional effects in our experiment compared with the competition between native species in Kozovits et al. study. In HL, the mean height of $P$. serotina was $192 \pm 11 \mathrm{~mm}$, while the mean height of $Q$. petraea $95 \pm 2 \mathrm{~mm}$. P. serotina grew more dynamically, overtopping and shading $Q$. petraea seedlings, which caused $Q$. petraea to alter their leaf structure in response to this additional shading. In ML and HL, our invasive species benefitted directly from higher light availability for photosynthesis and indirectly by shading out the native species and effectively reducing its growth (Craine and Dybzinski 2013).

\section{Photosynthetic capacity and efficiency}

There are conflicting results in the literature as to whether species' gas exchange rates vary among invasive and native species and whether the difference confers growth 
advantages (Funk 2008). In our study, the values of LMA suggest that $P$. serotina should have higher photosynthetic capacity per unit leaf dry mass than $Q$. petraea. However, during the growing season, the invasive maintained $A_{\max }$ and $R_{d}$ at a lower and more stable level compared with the native, rejecting hypothesis 2 . Thus, our results suggest that an invasive does not need to have higher $A_{\max }$ to overtop its native competitor growing in the same niche. Our results are inconsistent with an earlier study by Leishman et al. (2007) who compared 75 native and 90 invasive plants and found that invasive species had higher $\mathrm{A}_{\max }$ than natives, as well as another study showing that two invasive Rubus species had higher $\mathrm{A}_{\max }$ compared with their native congeners (McDowell 2002). However, Boyd et al. (2009) found that the invasive Berberis thunbergii DC. did not differ in $\mathrm{A}_{\max }$ from the native Kalmia latifolia $\mathrm{L}$. and Vaccinium corymbosum $\mathrm{L}$. Additionally, our study species $P$. serotina in its native range showed higher net $\mathrm{CO}_{2}$ assimilation rates than two invasive shrubs (Harrington et al. 1989). Thus, our results indicate that photosynthetic activity alone, despite its fundamental role in the acquisition of energy required for growth, does not appear to drive the invasive success of $P$. serotina.

Phenological differences in leaf flushing, senescence, and growing season length may to some extent explain differences in carbon gain and growth of the invasive and native species (Zohner and Renner 2017). Q. petraea emerges from acorns and begins leaf bud flushing 2-3 weeks earlier than P. serotina. However, the latter continues height growth for a longer period of time and under the shade of a tree canopy, and it can retain photosynthetically functional leaves further into the fall and occasionally in winter. In the natural range of $P$. serotina in Wisconsin, USA, this lengthening of the growing season does not occur, and in fact some invasives have been found to retain leaves for up to two weeks longer than $P$. serotina (Harrington et al. 1989). Thus, invasive $P$. serotina appears to use late bud flushing to avoid late spring frosts and extended leaf longevity in the fall to increase its annual carbon gain and gain a growth advantage over some native species.

In our study, the strong competitive pressure and lower $\mathrm{A}_{\max }$ for $\mathrm{P}+\mathrm{Q}+\mathrm{L}$ resulted in decreased PNUE compared with $\mathrm{P}$ (Table S7, Figs. 3b, 4b). In contrast, for the native species, $\mathrm{Q}+\mathrm{P}+\mathrm{L}$ did not change $\mathrm{A}_{\max }$ compared with $\mathrm{Q}$, while $\mathrm{Q}+\mathrm{L}$ showed the highest values of $\mathrm{A}_{\max }$ compared with the other treatment combinations. Thus, the results did not confirm hypothesis 4 , which stated that mulching with $P$. serotina leaves would have a negative allelopathic effect on the photosynthetic rate of $Q$. petraea. It is possible that mulching instead had positive nutritional effects on $Q$. petraea. The leaves of $P$. serotina used for mulching may have been a source of nitrogen that was utilized in photosynthetic processes and invested into photosynthetic structures, contributing to an increase in $\mathrm{CO}_{2}$ uptake or prunasin production used for chemical defense (Neilson et al. 2013). If prunasin from leaves used for mulching was microbiologically degraded in soil, it may also provide $Q$. petraea with nitrogen that could contribute to an increase in $\mathrm{A}_{\max }$. However, the biochemical mechanism of this process remains unclear (Ubalua 2010).

PNUE increased with light in our experiment, but differences between light treatments were more distinguishable in Q. petraea (Tables S7, S8). $\mathrm{P}+\mathrm{Q}+\mathrm{L}$ reduced PNUE compared with $\mathrm{P}$ due to lower $\mathrm{A}_{\max }$ and leaf nitrogen concentrations (34 $\mathrm{mg} \mathrm{N} \mathrm{g}^{-1} \mathrm{DM}$ in $\mathrm{P}$ and $31 \mathrm{mg} \mathrm{g}^{-1}$ in $\mathrm{P}+\mathrm{Q}+\mathrm{L}$ ) (Fig. 4b). P. serotina may have invested some amount of nitrogen into non-photosynthetic compounds such as prunasin for chemical defense at the expense of $A_{\max }$ (Patton et al. 1997). Other studies have observed similar trends regarding nitrogen use and chemical defense compounds; for example, a study of Eucalytpus cladocalyx found that there was an approximately proportional increase in cyanogenic glycoside concentration with leaf nitrogen concentration (Gleadow et al. 1998). Our results suggest that in the introduced range in Polish forests, $P$. serotina seedlings that occur en masse can assimilate and accumulate high levels of nitrogen, making it less available for $Q$. petraea (Craine and Dybzinski 2013).

Photosynthetic energy use efficiency $(\mu \mathrm{mol} \mathrm{CO} 2(\mathrm{~kg}$ glucose $\left.)^{-1} \mathrm{~s}^{-1}\right)$ and nitrogen use efficiency $(\mu \mathrm{mol} \mathrm{CO} 2(\mathrm{~g}$ nitrogen $)^{-1} \mathrm{~s}^{-1}$ ) have been found to be higher for invasive compared to native species, while costs of leaf construction are lower (Boyd et al. 2009). Our results confirmed this, as in $P$. serotina, the respiratory costs of photosynthesis were lower than in $Q$. petraea independent of sampling date, light environment or treatment combination, which supports hypothesis 2 . This is consistent with prior studies showing that invasive species have lower respiratory costs compared with native species (Leishman et al. 2010; McDowell 2002; Pattison et al. 1998). Although the mean values of area- and mass-based $\mathrm{A}_{\max }$ were lower for P. serotina, $\mathrm{A}_{\text {crown }}$ per individual $P$. serotina seedling was higher than that of $Q$. petraea (Tables S5, S6), confirming hypothesis 2. Moreover, $\mathrm{A}_{\text {crown }}$ of $Q$. peteaea was also competitively suppressed by the presence of the invasive in the $\mathrm{Q}+\mathrm{P}+\mathrm{L}$ treatment as compared to $\mathrm{Q}+\mathrm{L}$ (Table S6).

The invasiveness of $P$. serotina was further enhanced when seedlings were exposed to HL, which was reflected by a more significant increase in $\mathrm{A}_{\text {crown }}$ compared with the native and more conservative $Q$. petraea.

\section{Biomass allocation}

P. serotina allocated more biomass to leaves and had higher LAR, $A_{L}$ and RGR, which conveyed an advantage in the competition for light compared with $Q$. petraea (Figs. 5, 6). This interspecific difference in biomass allocation was 
important in ML and HL, but not in LL where both species were under a high degree of light stress. Consistent with the results of Reich et al. (1998), greater RGR of $P$. serotina resulted from higher LAR and $\mathrm{A}_{\mathrm{L}}$ compared with $Q$. petraea. The behavior of $P$. serotina in response to increasing light was to some extent similar to that of invasive Bischofia javanica Blume which also showed higher morphological plasticity, faster leaf production and higher tolerance to photoinhibition compared with native species (Yamashita et al. 2000, 2002). Interestingly, in our study, the invasive species invested in leaf tissue and high RGR under light deficit and competition/mulching in $\mathrm{P}+\mathrm{Q}+\mathrm{L}$, but in $\mathrm{HL}$ leaf production and RGR were reduced by the competition in $\mathrm{P}+\mathrm{Q}$ (Fig. 5). These differences between competition treatments were noticed when shoot/root ratios were compared (data not shown). The morphological response of $P$. serotina to interspecific competition was more plastic than that of $Q$. petraea. Our results are in agreement with Kozovits et al. (2005), who showed that $F$. sylvatica displayed smaller crown volumes per unit of shoot biomass in species mixtures compared with monoculture, whereas $P$. abies enhanced space sequestration in mixed culture.

In conclusion, our study shows that light environment has a stronger effect on photosynthesis than the effects of interspecific competition and/or allelopathic effects of $P$. serotina leaves. The response to light of both study species was similar, but in agreement with hypothesis 5, invasive $P$. serotina displayed higher morphological plasticity and was better able to cope with competition than native $Q$. petraea. Our results suggest that the quantum yield of PSII of an invasive species can increase in presence of a competitor and that the higher plasticity of leaf absorbed light energy partitioning appears to give a competitive advantage to invasive $P$. serotina over native $Q$. petraea. $P$. serotina seedlings allocated proportionally more biomass to aboveground tissues, allowing them to capture a greater amount of light and photosynthesize more efficiently. In contrast, the native seedlings invested more in root development which gave them an advantage in belowground competition for water and nitrogen. Additionally, $Q$. petraea did not decrease area- and mass-based $\mathrm{A}_{\max }$ and PNUE under the pressure of competition and positively responded to mulching with $P$. serotina leaves. Therefore, despite the similar ecological requirements of invasive $P$. serotina and native $Q$. petraea, they can co-occur in the same environment due to their different strategies of biomass allocation, partitioning of leaf absorbed light energy, and photosynthetic efficiency.

Acknowledgements This study was supported by Ministry of Science and Higher Education Research Grant no. N309 02639. We thank two Anonymous Reviewers for valuable comments which greatly improved the manuscript.
Open Access This article is distributed under the terms of the Creative Commons Attribution 4.0 International License (http://creativeco mmons.org/licenses/by/4.0/), which permits unrestricted use, distribution, and reproduction in any medium, provided you give appropriate credit to the original author(s) and the source, provide a link to the Creative Commons license, and indicate if changes were made.

\section{References}

Abrams P (1983) The theory of limiting similarity. Annu Rev Ecol Syst 15:359-376

Alba C, Hufbauer R (2012) Exploring the potential for climatic factors, herbivory, and co-occurring vegetation to shape performance in native and introduced populations of Verbascum thapsus. Biol Invasions 14:2505-2518

Bais HP, Vepachedu R, Gilroy S, Callaway RM, Vivanco JM (2003) Allelopathy and exotic plant invasion: from molecules and genes to species interactions. Science 301:1377-1380

Baker HG (1965) Characteristics and modes of origin of weeds. In: Baker HG, Stebbins GL (eds) The genetics of colonizing species. Academic Press, New York

Balandier P (2005) Designing forest vegetation management strategies based on the mechanisms and dynamics of crop tree competition by neighbouring vegetation. Forestry 79:3-27

Baruch Z, Goldstein G (1999) Leaf construction cost, nutrient concentration, and net $\mathrm{CO}_{2}$ assimilation of native and invasive species in Hawaii. Oecologia 121:183-192

Boyd J, Xu C-Y, Griffin K (2009) Cost-effectiveness of leaf energy and resource investment of invasive Berberis thunbergii and co-occurring native shrubs. Can J For Res 39:2109-2118

Callaway RM, Aschehoug ET (2000) Invasive plants versus their new and old neighbors: a mechanism for exotic invasion. Science 290:521-523

Closset-Kopp D, Chabrerie O, Valentin B, Delachapelle H, Decocq G (2007) When Oskar meets Alice: does a lack of trade-off in $\mathrm{r} / \mathrm{K}$-strategies make Prunus serotina a successful invader of European forests? For Ecol Manag 247:120-130

Closset-Kopp D, Saguez R, Decocq G (2011) Differential growth patterns and fitness may explain contrasted performances of the invasive Prunus serotina in its exotic range. Biol Invasions 13:1341-1355

Craine JM, Dybzinski R (2013) Mechanisms of plant competition for nutrients, water and light. Funct Ecol 27:833-840

Csiszár Á, Korda M, Schmidt D, Šporčić D, Süle P, Teleki B, Tiborcz V, Zagyavai G, Bartha D (2013) Allelopathic potential of some invasive plant species occurring in Hungary. Allelopath $\mathrm{J}$ 31:309-318

Daehler CC (2003) Performance comparisons of co-occurring native and alien invasive plants: implications for conservation and restoration. Annu Rev Ecol Sys 34:183-211

Davis MA, Grime JP, Thompson K (2000) Fluctuating resources in plant communities: a general theory of invasibility. J Ecol 88:528-534

Demmig-Adams B, Adams III WW (1996) Xanthophyll cycle and light stress in nature: uniform response to direct sunlight among higher plant species. Planta 198:460-470

Demmig-Adams B, Adams III WW (2006) Photoprotection in an ecological context: the remarkable complexity of thermal energy dissipation. New Phytol 172:11-21

Demmig-Adams B, Adams III WW, Barker DH, Logan BA, Bowling DR, Verhoeven AS (1996) Using chlorophyll fluorescence to 
assess the fraction of absorbed light allocated to thermal dissipation of excess excitation. Physiol Plantarum 98:253-264

Ellsworth DS, Reich PB (1992) Leaf mass per area, nitrogen content and photosynthetic carbon gain in Acer saccharum seedlings in contrasting forest light environmnents. Funct Ecol 6:423-435

Firn J, MacDougall AS, Schmidt S, Buckley YM (2010) Early emergence and resource availability can competitively favour natives over a functionally similar invader. Oecologia 163:775-784

Flexas J, Medrano H (2002) Energy dissipation in $\mathrm{C}_{3}$ plants under drought. Funct Plant Biol 29:1209-1215

Forestry Compendium (2005) Prunus serotina, Quercus petraea. In: Forestry Compendium (ed) Global edition. CAB International, Wallingford

Funk JL (2008) Differences in plasticity between invasive and native plants from a low resource environment. J Ecol 96:1162-1173

Genty B, Briantais J-M, Baker NR (1989) The relationship between the quantum yield of photosynthetic electron transport and quenching of chlorophyll fluorescence. Biochim Biophys Acta 990:87-92

Gleadow RM, Foley WJ, Woodrow IE (1998) Enhanced $\mathrm{CO}_{2}$ alters the relationship between photosynthesis and defence in cyanogenic Eucalyptus cladocalyx F. Muell. Plant Cell Environ 21:12-22

Grime JP (1974) Vegetation classification by reference to strategies. Nature 250(5461):26-31

Grime JP (1977) Evidence for the existence of three primary strategies in plants and its relevance to ecological and evolutionary theory. Am Nat 111:1167-1194

Halarewicz A (2011) The reasons underlying the invasion of forest communities by black cherry, Prunus serotina and its subsequent consequences. Forest Res Pap 72:267-272

Harrington RA, Brown BJ, Reich PB (1989) Ecophysiology of exotic and native shrubs in Southern Wisconsin. I. Relationship of leaf characteristics, resource availability, and phenology to seasonal patterns of carbon gain. Oecologia 80:356-367

Heberling JM, Fridley JD (2013) Resource-use strategies of native and invasive plants in Eastern North American forests. New Phytol 200:523-533

Hendrickson L, Furbank RT, Chow WS (2004) A simple alternative approach to assessing the fate of absorbed light energy using chlorophyll fluorescence. Photosynth Res 82:73-81

Hierro JL, Callaway RM (2003) Allelopathy and exotic plant invasion. Plant Soil 256:29-39

Hikosaka K, Terashima I (1996) Nitrogen partitioning among photosynthetic components and its consequences in sun and shade plants. Funct Ecol 10:335-343

Hunt R (1982) Plant growth curves. The functional approach to plant growth analysis. Edward Arnold, London

Keane RM, Crawley MJ (2002) Exotic plant invasions and the enemy release hypothesis. Trends Ecol Evol 17:164-169

Kenk G (1993) New perspectives in German oak silviculture. Ann For Sci 50:563-570

Koutika L-S, Vanderhoeven S, Chapuis-Lardy L, Dassonville N, Meerts P (2007) Assessment of changes in soil organic matter after invasion by exotic plant species. Biol Fertil Soils 44:331-341

Kozovits AR, Matyssek R, Winkler JB, Göttlein A, Blaschke H, Grams TEE (2005) Above-ground space sequestration determines competitive succes in juvenile beech and spruce trees. New Phytol 167:181-196

Leavesley HB, Li L, Prabhakaran K, Borowitz JL, Isom GE (2008) Interaction of cyanide and nitric oxide with cytochrome c oxidase: implications for acute cyanide toxicity. Toxicol Sci 101:101-111

Lei TT, Lechowicz MJ (1998) Diverse responses of maple saplings to forest light regimes. Ann Bot Lond 82:9-19
Leishman MR, Haslehurst T, Ares A, Baruch Z (2007) Leaf trait relationships of native and invasive plants: community- and globalscale comparisons. New Phytol 176:635-643

Leishman MR, Thomson VP, Cooke J (2010) Native and exotic invasive plants have fundamentally similar carbon capture strategies. J Ecol 98:28-42

Mack RN (1996) Predicting the identity and fate of plant invaders: emergent and emerging approches. Biol Conserv 78:107-121

Mangla S, Sheley RL, James JJ, Radosevich SR (2011) Intra and interspecific competition among invasive and native species during early stages of plant growth. Plant Ecol 212:531-542

Marquis AD (1990) Prunus serotina Ehrh. Black Cherry. In: Burns RM, Honkala BH (eds) Silvics of North America: 2. Hardwoods-Agriculture Handbook 654. Department of Agriculture, Forest Service, Washington

Maxwell K, Johnson GN (2000) Chlorophyll fluorescence - a practical guide. J Exp Bot 51:659-668

McDowell SCL (2002) Photosynthetic characteristics of invasive and noninvasive species of Rubus (Rosaceae). Am J Bot 89:1431-1438

Molina-Montenegro MA, Penuelas J, Munné-Bosch S, Sardans J (2012) Higher plasticity in ecophysiological traits enhances the performance and invasion success of Taraxacum officinale (dandelion) in alpine environments. Biol Invasions 14:21-33

Möllerová J (2005) Notes on invasive and expansive trees and shrubs. J For Sci 2005:19-23

Neilson EH, Goodger JQD, Woodrow IE, Møller BL (2013) Plant chemical defense: at what cost? Trends Plant Sci 18:250-258

Niinemets Ü, Bilger W, Kull O, Tenhunen JD (1998) Acclimation to high irradiance in temperate deciduous trees in the field: changes in xanthophyll cycle pool size and in photosynthetic capacity along a canopy light gradient. Plant Cell Environ 21:1205-1218

Niyogi KK (1999) Photoprotection revisited: genetic and molecular approaches. Annu Rev Plant Phys 50:333-359

Novoplansky A (2009) Picking battles wisely: plant behaviour under competition. Plant Cell Environ 32:726-741

Oguchi R, Hikosaka K, Hiura T, Hirose T (2008) Costs and benefits of photosynthetic light acclimation by tree seedlings in response to gap formation. Oecologia 155:655-675

Oguchi R, Hiura T, Hikosaka K (2017) The effect of interspecific variation in photosynthetic plasticity on 4-year growth rate and 8 -year survival of understorey tree seedlings in response to gap formations in a cool-temperate deciduous forest. Tree Physiol 37:1113-1127

Parker JD, Torchin ME, Hufbauer RA, Lemoine NP, Alba Ch, Blumenthal DM, Bossdorf O, Byers JE, Dunn AM, Heckman RW et al (2013) Do invasive species perform better in their new ranges? Ecology 94:985-994

Pattison RR, Goldstein G, Ares A (1998) Growth, biomass allocation and photosynthesis of invasive and native Hawaiian rainforest species. Oecologia 117:449-459

Patton CA, Ranney TG, Burton JD, Walgenbach JF (1997) Natural pest resistance of Prunus taxa to feeding by adult Japanese beetles: Role of endogenous allelochemicals in host plant resistance. J Hortic Sci 122:668-672

Peet R, Christensen N (1987) Competition and tree death. Bioscience 37:587-595

Rascher U, Liebieg M, Lüttge U (2000) Evaluation of instant lightresponse curves of chlorophyll fluorescence parameters obtained with a portable chlorophyll fluorometer on site in the field. Plant Cell Environ 23:1397-1405

Reich BP, Walters BM, Ellsworth SD (1992) Leaf life-span in relation to leaf, plant, and stand characteristics among diverse ecosystems. Ecol Monogr 62:365-392 
Reich BP, Walters BM, Ellsworth SD, Vose JM, Volin JC, Gresham C, Bowman WD (1998) Relationships of leaf dark respiration to leaf nitrogen, specific leaf area and leaf life-span: a test across biomes and functional groups. Oecologia 114:471-482

Reinhart KO, Packer A, Van der Putten WH, Clay K (2003) Plant-soil biota interactions and spatial distribution of black cherry in its native and invasive ranges. Ecol Lett 6:1046-1050

Robakowski P (2005) Susceptibility to low-temperature photoinhibition in three conifer tree species differing in successional status. Tree Physiol 25:1091-1100

Robakowski P, Bielinis E (2011) Competition between sessile oak (Quercus petraea) and black cherry (Padus serotina): dynamics of seedlings growth. Pol J Ecol 59:297-306

Robakowski P, Bielinis E, Stachowiak J, Mejza I, Bułaj B (2016) Seasonal changes affect root prunasin concentration in Prunus serotina and override species interactions between P. serotina and Quercus petraea. J Chem Ecol 42:202-214

Sendall K, Reich PB (2013) Variation in leaf and twig CO2 flux. as a function of plant size a comparison of seedlings, saplings and trees. Tree Physiol 33:713-729

Swain E, Li CP, Poulton JE (1992) Development of the potential for cyanogenesis in maturing black cherry (Prunus serotina Ehrh.) fruits. Plant Physiol 98:1423-1428

Ubalua AO (2010) Cyanogenic glycosides and the fate of cyanide in soil. Aust J Crop Sci 4:223-237
Valladares F, Wright SJ, Lasso E, Kitajima K, Pearcy RW (2000) Plastic phenotypic response to light of 16 congeneric shrubs from a Panamian rainforest. Ecology 81:1925-1936

van Kleunen M, Weber E, Fischer M (2010) A meta-analysis of trait differences between invasive and non-invasive plant species. Ecol Lett 13:235-245

Vetter J (2000) Plant cyanogenic glycosides. Toxicon 38:11-36

Wright IJ, Reich PB, Westoby M, Ackerly DD, Baruch Z, Bongers F, Cavender-Bares J, Chapin T, Cornelissen JHC, Diemer M et al (2004) The worldwide leaf economics spectrum. Nature 428:821-827

Yamashita N, Ishida A, Kushima H, Tanaka N (2000) Acclimation to sudden increase in light favoring an invasive over native trees in subtropical islands. Jpn Oecol 125:412-419

Yamashita N, Koike N, Ishida A (2002) Leaf ontogenetic dependence of light acclimation in invasive and native subtropical trees of different successional status. Plant Cell Environ 25:1341-1356

Yuan Y, Guo W, Ding W, Wang R (2013) Competitive interaction between the exotic plant Rhus typhina $\mathrm{L}$. and the native tree Quercus acutissima Carr. in Northern China under different soil N: P ratios. Plant Soil 372:389-400

Zohner CM, Renner SS (2017) Innately shorter vegetation periods in North American species explain native-non-native phenological asymmetries. Nat Ecol Evol. https://doi.org/10.1038/s4155 9-017-0307-3 